\title{
Three decades of subsidiary exits: Parent firm financial performance and moderators
}

\author{
by
}

\section{Dafnis N. Coudounaris*, María Orero-Blat and María Rodríguez-García}

*Corresponding author's name: Dafnis N. Coudounaris, Associate Professor in Innovation Management, School of Economics and Business Administration, University of Tartu, Tartu, Estonia. Mailing address: University of Tartu, School of Economics and Business

Administration, J. Liivi 4-104, 50409 Tartu, Estonia, Telephone: +372 58339575, E-mail:

dafnis.coudounaris@ut.ee

Acknowledgments: The work by Dr Dafnis N. Coudounaris was supported by the institutional research funding IUT (IUT20-49) of the Estonian Ministry of Education and Research. 


\title{
Three decades of subsidiary exits: Parent firm financial performance and moderators
}

\begin{abstract}
This study aimed to find important constructs and relationships among models of subsidiary divestment during the period from 1989 to 2018 using correlation matrices of 80 studies, the selection of which was based on six criteria. It revealed eight important constructs, namely firm innovativeness, environmental factors in the target country, type of experience, organizational characteristics, investment strategy, parent firm financial performance, subsidiary divestment, and the moderating effects of advertising intensity and product diversification. Furthermore, it shed light on seven relationships that should be considered in future attempts to measure or assess parent performance related to its antecedents and subsidiary divestment. Moreover, advertising intensity and product diversification were respectively weakening and strengthening moderators on firm financial performance, and advertising intensity was a weakening moderator between organizational characteristics and subsidiary divestment. The implementation of a product diversification policy did not assist in preventing subsidiary divestment. Conclusions, implications, limitations, and future research were discussed.
\end{abstract}

Keywords: subsidiary divestment; important relationships; correlations; moderators; multinomial logistic regression analysis.

\section{Introduction}

International business (IB) studies on disinvestments are important, as these are routine for multinational corporations (MNCs) when re-structuring foreign direct investments (FDIs) abroad (Malik, 2018), depending on various issues such as demand versus supply of manufactured products, level of consumers' income, size of market and other macroeconomic factors (see Figure 1). Divestment is routine nowadays for MNCs, whose chosen markets may be declining because of environmental changes, whereas other markets, where new opportunities are developing, need FDI. Four decades have passed since the initial research in this area. Past research identifies several factors that influence MNC foreign subsidiary exits such as firm innovativeness, firm financial performance, macro and microeconomic factors in the target country, environmental factors in the target country, type of experience, organizational characteristics/factors, and the chosen 
investment strategy (Pot et al., 2018). Previous studies (Lee and Madhavan, 2010; Coudounaris, 2017) indicate that the factors above have different influences on the divestment of subsidiaries. However, few previous studies have measured the influence of these factors, and there is no single study that has tested the fit of similar models with the assistance of structural equation modeling. This is because of the difficulty of collecting primary data on the topic, as managers are reluctant to provide information on the failures of FDIs. This statistical gap remains unresolved, although by using secondary data one can find the causality of the intervening variables and whether there is a positive or negative effect on divestment. However, the positive or negative effect on divestment depends on the phrasing of the proposition.

The strategy of disinvestment, otherwise called divestment, first appeared four decades ago as an independent chapter in a book published by Brooks and Remmers (1977, pp. 59-73), indicating the importance of this strategy to MNCs. Later, Boddewyn (1979), Caves (1995), and Benito (1997a) call for more investigation on the drivers of divestment, and the effects of this strategy. Benito (2005) questions why Rugman and Brewer (2001) do not mention anything about divestment in their anthology on the state-of-the-art in IB research. Furthermore, different studies by Lee and Madhavan (2010) and Coudounaris (2017) (see Endnote) examine numerous empirical studies on divestments and firm performance in meta-analyses.

Current literature on divestment uses the construct of subsidiary divestment as a possible outcome. No existing study, however, explores whether other possible outcome variables, such as parent firm performance, may also be used in the context of subsidiary divestment. Firm export performance is often used as a dependent variable, as in the meta-analysis by Leonidou, Katsikeas, and Sammie (2002). However, in the context of subsidiary exit, divestment was used as an independent variable. Furthermore, at least ten studies on divestment/subsidiary exit exclude either 
divestment or subsidiary exit and are focused on performance/profitability/return on assets (ROA) (Kaul, Nary and Singh, 2018; Meschi and Métais, 2015; Song, 2015; Elfenbein and Knott, 2014; Berry, 2013; Cui and Kumar, 2012; Fisch and Zschoche, 2012; Chang and Singh, 1999; Bergh, 1997; Markides, 1995). As the literature on divestment is rather limited, one cannot limit the possibility of the parent firm performance being not only an independent factor explaining subsidiary divestment, but also a dependent variable explained by the antecedent factors of divestment. Parent firm performance, profitability, and ROA are used as dependent variables in the ten studies mentioned above. According to Heidary et al. (2019), ROA is identified as the main criterion for assessing performance.

The reader should understand that the data used in this study are correlations and not primary data collected through surveys. Because the use of correlations as a dataset limits subsidiary divestment to a binary variable without variability, parent firm performance correlations can proxy for this variable.

Furthermore, in the study by Coudounaris (2017), meta-analysis of both advertising intensity and product diversification are used as direct effects on subsidiary exit. However, this study used both constructs as moderators instead, because they are both used as moderators in firm performance (Nijs, Dekimpe, Steenkamp, and Hanssens, 2001; Hitt, Tihanyi, Miller and Connelly, 2006). It was not within the scope of this study to perform another meta-analysis, but rather to analyze the effects of the advertising intensity and product diversification moderators between the determinants of divestment and parent firm performance-a research gap that has not been thoroughly investigated in the past. Therefore, this study aims to examine what determinants of divestment influence the parent firm performance, and in turn, their effect on subsidiary divestment. 
The study has two main objectives: to examine, on the one hand, the importance of the moderating effects of advertising intensity and product diversification on parent firm performance and subsequently, subsidiary performance, and on the other hand, their moderating effects on the relationships between parent firm performance antecedents and subsidiary divestment. For example, advertising intensity is highlighted in the following studies: Hoskisson et al. (1994), Mariotti and Piscitello (1999), Berry (2004), Lu and Hébert (2005), Chan et al. (2006), Berry (2010), Pattnaik and Lee (2014), and Song (2014b). Moreover, product diversification is thoroughly examined in such studies as Lu and Xu (2006), Hayward and Shimizu (2006), Xu and $\mathrm{Lu}$ (2007), and Brauer and Wiersema (2012).

The recent economic crisis of 2008-2011, which resulted in many cases of subsidiary failure worldwide (Jung et al., 2018), triggered substantial interest among MNCs in the re-investigation of the divestment strategy and other strategies to be implemented or examined, that is, the moderating effects of product diversification and advertising intensity.

Coudounaris (2017) reveals eleven significant relationships among six constructs, namely parent firm factors, environmental factors in the target country, experience, organizational characteristics, investment strategy, and subsidiary divestment.

As stated above, this research aimed to identify existing relationships in the IB literature regarding the determinants that influence subsidiary divestment and to find gaps in the subsidiary divestment/survival literature by performing multinomial logistic regressions. It is worth noting that Mata and Portugal's (2000) study shows the failure rates of 1033 foreign entrants into the Portuguese market between closures and divestment in the acquisition, greenfield, minority, majority, and fully owned FDIs. They conclude that while ownership arrangements and organizational structure affect the likelihood of divestment, they do not affect closures. Greenfield 
entrants are more likely to shut down than to divest, and human capital affects closure and divestment in the same manner. These findings lead to the question of what the determinants of divestment are, with respect to parent firm performance.

Therefore, this study proposed a model that shows how the antecedents influence the financial performance of the parent firm and subsidiaries and, in turn, affect subsidiary divestment.

Firm financial performance is measured by parent performance (profitability and ROA) and subsidiary performance. Both advertising intensity and product diversification are tested because both are frequently used as the main strategies of MNCs.

MNCs often divest when the subsidiary performance is very poor; however, occasionally headquarters may still demand divestment despite satisfactory performance. The former can be explained by the performance risk of the subsidiary. The latter case can be explained as a prisoner's dilemma of the relational risk between headquarters and the subsidiary. The following dilemmas are raised: first, why underperforming subsidiaries are not divested by headquarters, and second, why those that excel are still divested by headquarters. The former can be justified when the relationship risk between headquarters and subsidiary is low and the trust and commitment relationships between them are high. The latter can be justified by the resource-based view that resources are limited. In this case, managers of headquarters can focus on the needs of the company and other attractive opportunities abroad. Consequently, headquarters can divest a subsidiary with good performance from one country to another and move its facilities and employees to a market with good prospects and strengthen the company's presence in that market.

The contribution of this study is mainly the investigation of the six relationships of the determinants of divestment on parent firm performance by using multinomial logistic regressions. The study shows that four out of five propositions are supported in Table 1 ( $2^{\text {nd }}$ model), and four 
relationships are significant, that is a) the relationship of $R \& D$ to parent financial performance, $b$ ) international experience and divestiture experience to parent financial performance, c) parent size, subsidiary size, and subsidiary age to parent financial performance, and d) acquisition to parent financial performance. Furthermore, it reveals that advertising intensity is a significant weakening moderating factor between organizational characteristics and subsidiary divestment. However, product diversification is not a significant moderating factor between antecedents and subsidiary divestment. Moreover, advertising intensity and product diversification are respectively weakening and strengthening moderators on firm financial performance (Pérez et al., 2018).

This study also suggests theoretical and managerial implications related to these four relationships compared with an earlier study by Coudounaris (2017). Coudounaris reveals eleven significant relationships related to subsidiary exit using meta-analytical correlations, rather than the multinomial logistic regression used in this study.

In the remainder of the article, the authors focus on a related literature review in Section 2 and Section 3 presents the research methodology. Finally, the results are presented in Section 4, followed by a discussion of the conclusions, managerial implications, limitations of the study, and future research direction in Section 5.

\section{Literature review}

\subsection{Theoretical background and foreign divestment today}

Brooke and Remmers (1977, pp. 59-73) discuss the subject of divestment in their textbook "The International Firm." As they explain, "it proved to be difficult to collect information on this subject because business executives are reluctant to discuss divestment, which carries a strong flavor of failure. Some divestments result from failure or hostile government action" (pp.59-73). It is worth 
analyzing whether divestitures result from economic cycles or are a response to proactive strategic decision making (Moschiery and Mair, 2008).

As we mention in the introduction, two theories can explain the paradox of the prisoner's dilemma (Rapoport and Chammah, 1965; Rapoport, 1967), namely that headquarters divest profitable subsidiaries and at the same time do not divest non-profitable subsidiaries. The two theories that may explain this behavior are the resource-based view (RBV) and the relational risk between headquarters and subsidiaries. The RBV (Barney, 1991 and 2001; Barney, Wright and Ketchen, 2001; Barney, Ketchen Jr., and Wright, 2011) considers that MNCs have limited resources and therefore headquarters may divest operations in one country to assist business operations in another. Also, the relational risk between headquarters and subsidiaries is variable, depending on the trust/commitment relationships between them. When the relational risk is low because of an excellent trust/commitment relationship, then headquarters may decide not to divest the operations of a subsidiary with low profitability and/or with some losses. However, when the relational risk between headquarters and subsidiary is high because of a problematic trust/commitment relationship, then headquarters may divest the operations of a subsidiary which has high profitability in one market to assist the operations of another subsidiary in another market. Profitability is one of the measures of subsidiary performance; however, it is not such an important aspect of decision-making in relationships between headquarters and subsidiaries regardless of the level of relationship risk. What is most important is how weak or strong the trust/commitment relationship is between them. According to Hwang (2005, pp. 559-561), trust and time horizon are important in this relationship. Indeed, when there is only one business in question, the business relationship between headquarters and its' subsidiary does not consider trust or relational risk. The 
time horizon depends on the existing and future environmental factors that the relationship may face.

\subsection{Theoretical backgrounds of previous studies}

In Arte and Larimo's (2019) recent study, based on 53 previously published papers, they enumerate the different theoretical frameworks used by these papers namely, knowledge-based view, transaction cost economics, cultural dimensions approach, eclectic paradigm (OLI framework), institution-based view, economic geography-based view, the network approach and social exchange theory, and real options theory.

There has been considerable research since the late 1960s on divestments such as that by Sachdev (1976), who study the disinvestment policies for MNCs. Later, Boddewyn and Torneden (1973) study US foreign divestment, indicating an increase in divestment from 1967 to 1971. Furthermore, Boddewyn (1979) finds that poor performance is one of the financial reasons for divestment; however, there are cases when subsidiaries are profitable but are still divested. Boddewyn (1983) examines whether the absence of FDI factors accounts for foreign divestment and suggests that some FDI factors assume different configurations in foreign divestment theory and additional elements should be considered.

Williamson's $(1975,1985)$ transaction cost theory is partly used in this study as one of the aspects of the theoretical framework. However, transaction cost theory suffers from two weaknesses. First, it minimizes the cost, but does not maximize the value or the benefits. Second, it neglects the societal context, that is, trust and the time horizon (Hwang, 2006).

This study agrees with the contention that international managers are more likely to try to optimize the performance of their units. Furthermore, it uses Boddewyn's (1983) theory of foreign 
direct divestment or theory of reverse foreign direct investment (FDI) and the factors that influence divestments illustrated in Boddewyn (1979). Boddewyn (1979) finds that key foreign divestment factors were financial considerations, poor pre-investment analysis, adverse environmental conditions, lack of fit and resources, structural and organizational factors, external initiating pressures, and foreignness and national differences. One question arises: why is FDI an important part of divestment theory? Possibly, because an increase in FDI in any given country may affect the likelihood that a subsidiary will succeed over time; for instance, more FDI signals high-quality institutions, and thus subsidiaries have more resources to compete with (Andersson, Forsgren, and Holm, 2012)

In their investigation of 40 large diversified firms, Duhaime and Grant (1984) reveal three important factors influencing divestment decision-making, namely a business unit's strength, its association with other units of the firm, and its parent firm's financial strength compared with its competitors (the firm's financial strength was measured by return on equity). However, the effects of general economic growth and managerial attachment on the divestment decision were insignificant. Keomixaya and Ngamkroeckjoti (2011) find other factors influencing FDI: political and legal, economic and market, location, financial, and social and cultural factors. However, the results of Park and Park's (1999) earlier study, which investigates the determinants of FDI survival, suggest that a wholly-owned affiliate has a higher survival rate than a joint venture, an affiliate producing different products from its parent has a lower survival rate, an affiliate created through acquisition is less likely to survive than a greenfield, and the higher the political risks are in the host country, the lower the chances are for an affiliate to survive (Gu, Qian, and $\mathrm{Lu}, 2018$ ).

Another study highlights the importance of relational risk in the divestment decision. When a CEO deals with a relationship-specific investment, his/her level of perceived risk is of paramount 
importance (Minbaeva et al., 2003). If the perceived risk is very high for the specific investment, then the likelihood of divestment is also very high. The existing literature gives little consideration to the perceived risk in divestment decision-making and the factors which affect the level of the perceived risk of an investment. Mata and Freitas (2012) find that there is a difference between exit rates of foreign firms and domestic firms. They argue that foreign firms are more volatile, and their exit rates increase with age compared with those of domestic firms.

This study attempted to develop a model based on a) determinants of divestment (i.e., parent firm innovativeness, environmental factors in the target country, type of experience, organizational characteristics and investment strategy factors), b) central construct, (i.e., parent firm financial performance), and c) outcome (i.e., subsidiary divestment).

An earlier study by Coudounaris (2017) reveals that there are eleven significant relationships among six constructs, namely parent firm factors, environmental factors in the target country, experience, organizational characteristics, investment strategy, and subsidiary divestment (see the corresponding endnote for details).

\subsection{Model and propositions}

Over the years a great variety of factors influencing the divestment decision have been studied (Duhaime and Grant, 1984; Benito, 1997a and 1997b; Haynes, Thompson and Wright, 2003; Coudounaris, 2017). It is quite interesting that Duhaime and Grant (1984), Benito and Welch (1997), and Moliterno and Wiersema (2007) all include parent firm performance as one of these factors. By contrast, other studies investigate the effect of divestment on firm performance (Haynes, Thompson and Wright, 2002; Lee and Madhavan, 2010; Brauer and Schimmer, 2010). This study investigates parent firm performance, which mediates between determinants of 
divestment and subsidiary divestment, as well as the mediating effect of subsidiary performance between determinants of divestment and subsidiary divestment. Therefore, parent firm performance acts as the dependent variable (see Figure 1 and Table 1). In the following sections, we elucidate the propositions related to the conceptual model (see Figure 1).

Please place Figure 1 about here

\subsection{Parent firm innovativeness}

Parent firm innovativeness is a popular orientation in various disinvestment studies. In particular, various studies (Hoskisson et al., 1994; Mariotti and Piscitello, 1999; Berry, 2004; Lu and Hébert, 2005; Chan et al., 2006; Berry, 2010; Pattnaik and Lee, 2014; Song, 2014b) claim that R\&D intensity indicates the level of technology used by firms. This analysis includes parent firm innovativeness and uses R\&D intensity to measure it. It is noteworthy that the level of subsidiary R\&D depends on the MNC group- and subsidiary-level characteristics as well as locational factors (Cantwell and Mudambi, 2005). Although it has been proved that business intelligence has direct effects on performance through firm innovativeness and network learning, the other measurement of parent firm innovativeness, patent intensity, is excluded from the analysis as there were only three observations in the sample related to this variable. We posit that:

Proposition 1: Parent firm innovativeness is positively related to parent firm performance (profitability) and parent firm performance (profitability and ROA), but negatively related to subsidiary divestment. 
2.5 Environmental factors in the target country (economic factors, cultural distance, political risk, and host market uncertainty/risk).

Economic factors in the target country are influential in a firm's performance and potential market exit. Macro-economic factors have been examined by Song (2015), Song (2014a), Peng and Beamish (2014), Chung et al. (2013a), Chung et al. (2013), and Delios et al. (2008). Both per capita GDP and the GDP growth rate, which are macro-economic factors, harm subsidiary divestment in at least five studies. For example, the GDP growth rate has a positive relationship with parent performance/parent ROA (the greater the GDP growth rate, the greater the parent performance/parent ROA), but a negative relationship with subsidiary divestment (the greater the GDP growth rate, the lower the subsidiary divestment).

Furthermore, socio-political issues have been studied by different authors in the field of subsidiary divestments, namely Mariotti and Pitcitello (1999), Lu and Hébert (2005), Delios et al. (2008), Song (2014b), and Damarju et al. (2015). Specifically, these studies investigate cultural distance, political risk, and host market uncertainty. Cultural distance and political risk are most investigated in all the 80 studies (see Song, 2014a). It appears that the three environmental factors that this study investigates are diverse. Therefore, it is interesting to indicate whether each environmental factor is high or low. For example, high political risk is negatively related to parent profitability and positively related to high subsidiary divestment. We posit that:

Proposition 2: Environmental factors such as high political risk, cultural distance, and host market uncertainty/risk in the target country are negatively related to parent firm performance (measured by profitability) and parent firm performance (measured by profitability and ROA), but positively related to high subsidiary divestment. However, environmental factors such as high economic factors, (e.g. a substantial increase of GDP in 
the target country), are positively related to parent firm performance, but positively related to low subsidiary divestment.

\subsection{Type of experience (international experience, host country-specific experience, divestiture experience)}

Experience is an important aspect when investigating FDIs and divestments. There are three types of experience included in this analysis: international, host country-specific, and divestiture experience. It is worth noting that divestiture experience is investigated in studies by Shimizu and Hitt (2005) and Brauer and Schimmer (2010). According to Trapczynski's (2018) study, overall FDI experience is more important for successful start-up operations in advanced markets than in less developed countries. Institutional differences also influence subsidiary divestment in emerging economies (Dajms, 2019). We posit that:

Proposition 3: CEO international, host country-specific, and divestiture experience in subsidiaries or international joint ventures (IJVs), is positively related to parent firm performance (profitability) and parent firm performance (profitability and ROA), but negatively related to subsidiary divestment.

It is worth noting that Proposition 3 and proposition 1 are completely different. Proposition 3 positively relates the experience of headquarter CEOs with the parent firm performance, which in turn is negatively related to subsidiary divestment. However, proposition 1 positively relates firm innovativeness to parent firm performance, which is negatively related to subsidiary divestment. Both propositions deal with different relationships. 


\subsection{Organizational characteristics}

Organizational characteristics include relatedness/ unrelatedness (products, businesses), parent size, parentage, subsidiary/IJV size, and subsidiary/IJV age. As influential organizational factors, both relatedness (outcomes) and unrelatedness (products, businesses) have been studied separately by many scholars in their investigations related to subsidiary divestment, being cited in six studies (Shimizu and Hitt, 2005; Hayward and Shimizu, 2006; Lu and Xu, 2006; Xu and Lu, 2007; Lee et al., 2010; Brauer and Wiersema, 2012). However, in this analysis both relatedness and unrelatedness comprise one construct. Relatedness strategy, which is the other side of the coin of diversification, has been included in different studies such as $\mathrm{Lu}$ and $\mathrm{Xu}$ (2006), Hayward and Shimizu (2006), Xu and Lu (2007), and Brauer and Wiersema (2012). Although business relatedness/unrelatedness has a positive relationship with subsidiary divestment, it was included under organizational factors rather than as a separate independent factor (one variable construct). This factor could be added under organizational factors in the target country as it shows whether the business of the acquired or joint venture unit in the target country is associated with the business of the parent firm in the host country.

Characteristics such as parent size, parentage, subsidiary/IJV size, and subsidiary/IJV age have been discussed in many studies investigating divestments. For example, Chung et al. (2013), Durand and Vergne (2014), Dai et al. (2013), Decker and Mellewigt (2012), Demirbag et al. (2011), Kim et al. (2010), Belderbos and Zou (2009), Belderbos and Zou (2007), Xu and Lu (2007), Lu and Xu (2006), Lu and Hébert (2005), Delios and Beamish (2001), Mariotti and Piscitello (1999), and Li (1995) (see Table 1). We posit that: 
Proposition 4: Organizational characteristics are positively related to parent firm performance based on profitability and parent firm performance based on profitability and ROA, but negatively related to subsidiary divestment.

\subsection{Investment strategy}

The effect of acquisition and/or joint venture on subsidiary divestment has been the subject of many studies, notably Li (1995), Shaver et al. (1997), Mariotti and Piscitello (1999), Delios and Beamish (2001), Van Kranenburg et al. (2001), Belderbos and Zou (2006, 2007), Kim et al. (2010), Benavides-Espinosa and Roig-Dobon (2011), and Pattnaik and Lee (2014) Unsuccessful acquisitions due to hidden liabilities in the acquired company can lead to lower parent performance and increased subsidiary divestment. Likewise, unsuccessful mergers due to management conflict and staff cultural differences may lead to lower than expected performance and eventually to subsidiary divestment. For example, the 1998 Daimler-Chrysler merger ended with the sale of Chrysler in 2008, but then Daimler embarked on an alliance with Renault (Doole, Lowe and Kenyon, 2016, p. 192). Here, we posit that:

Proposition 5: Entry modes, that is, successful acquisitions and joint ventures, are positively related to parent firm performance based on profitability and parent firm performance based on profitability and ROA, but negatively related to subsidiary divestment.

\subsection{Parent firm financial performance and subsidiary performance}

Previous literature on divestment decisions highlights the important roles of both parent firm (Duhaime and Grant, 1984; Moliterno and Wiersema, 2007) and subsidiary (Duhaime and Schwnk, 1985) financial performance. Our analysis of the selected 80 studies (see Table 1 below) reveals that parent firm performance is a common construct in 52 studies. 
Among these 52 studies, 30 examine parent performance/profitability (Kaul et al., 2018; Mohr et al., 2018; Tan and Sousa, 2017; Dai et al., 2017; Zschoche, 2016; Damaraju et al., 2015; Song, 2015; Soule et al., 2014; Durand and Vergne, 2014; Elfenbein and Knott, 2014; Chung et al., 2013; Dai et al., 2013; Xia and Li, 2013; Cui and Kumar, 2012; Fisch and Zschoche, 2012; Kim et al., 2012; Brauer and Wiersema, 2012; Polidoro et al., 2011; Wu et al., 2011; Lee et al., 2010; Berry, 2010; Brauer and Schimmer, 2010; Anand et al., 2009; Lu and Hébert, 2005; Shimizu and Hitt, 2005; Delios and Beamish, 2001; Shaver et al., 1997; Markides, 1995; Baden-Fuller, 1989), and five (Xia and Li, 2013; Lee et al., 2010; Delios et al., 2008; Berry, 2004; and Haynes et al., 2000) relate to return on sales (ROS).

Furthermore, 16 studies are concerned with parent ROA (Hutzschenreuter et al., 2018; Kang et al., 2017; Meschi and Métais, 2015; Li and Liu, 2015; Farah, 2014; Pathak et al., 2014; Peng and Beamish, 2014; Berry, 2013; Kim et al., 2010; Delios et al., 2008; Moliterno and Wiersema, 2007; Hayward and Shimizu, 2006; Berry, 2004; Chang and Singh, 1999; Bergh, 1997; Hoskisson et al., 1994), and three relate to subsidiary ROA (Song and Lee, 2017; Kang et al., 2017; Chung et al., 2013a). Finally, 6 studies investigate subsidiary performance (Song, 2014a; Song, 2014b; Song, 2014c; Xia and Li, 2013; Hayward and Shimizu, 2006; Shimizu and Hitt, 2005).

Based on the above five types of financial performance, that is, parent performance/profitability (30 studies), ROS (5 studies), parent ROA (16 studies), subsidiary ROA (3 studies) and subsidiary performance (6 studies), Table 1 shows five separate models that have been developed based on multinomial logistic regressions, plus two aggregate models, namely, parent performance/profitability/ROS/parent ROA (50 studies) and subsidiary ROA/subsidiary performance (9 studies). The first model shows five significant relationships (i.e. R\&D intensity to parent performance, international experience to parent performance, divestiture experience to 
parent performance, parent size to parent performance, and acquisition to parent performance). The second model supports seven relations (R\&D intensity to parent performance/ROA, international experience to parent performance/ROA, divestiture experience to parent performance/ROA, parent size to parent performance/ROA, subsidiary size to parent performance/ROA, subsidiary age to parent performance/ROA, and acquisition to parent performance/ROA). In the third model, no relationship was supported by the multinomial logistic regression, and subsidiary performance seems to have no value in the analysis. We posit:

Proposition 6: Parent firm financial performance as measured by parent firm performance (profitability), parent firm performance (profitability and ROA), and subsidiary performance is negatively related to subsidiary divestment.

\subsection{Moderating factors: Advertising intensity and product diversification}

In a meta-analysis of divestitures, Lee and Madhavan (2010) called for further research on additional moderators to refine the knowledge related to divestiture and performance (Mudambi and Navarra, 2004). Their study found statistically significant moderators of type of performance measure, transaction format, transaction intent, and the firm's resource level. In this study, we explore the moderating effects of advertising intensity and product diversification, which are investigated in several studies. In particular, advertising intensity has been suggested as a strategic tool to avoid exits in various studies, such as Hoskisson et al. (1994), Mariotti and Piscitello (1999), Berry (2004), Lu and Hébert (2005), Chan et al. (2006), Berry (2010), Pattnaik and Lee (2014), and Song (2014b). This measure indicates the level of marketing advancements of firms, that is, expenditure on advertising divided by sales. Besides the factors mentioned above, previous literature investigates whether parent firms utilize product diversification as a tool for avoiding 
exits. In particular, the studies by Hoskisson et al. (1994), Li (1995), Bergh (1997), van Kravenburg et al. (2001), Berry (2004), Delios et al. (2008), Berry (2010), Wu et al. (2011), Chung et al. (2013), and Xia and Li (2013) suggest diversification as a defensive strategy to avoid exits. However, according to Markides (1995), the management of over-diversified large firms led to the divestment of non-core activities, although the timing of the divestment decision was based on the specific firm's conditions. We posit that:

Proposition 7: Advertising intensity and product diversification positively influence the relationships between determinants of divestment and firm financial performance/subsidiary divestment.

\section{Research methodology}

\subsection{Selection criteria used in gathering different papers on subsidiary/ IJV divestment}

The Appendix includes 80 studies among more than one hundred in the area of subsidiary divestments. Recently, some studies have been developed in similar areas such as deinternationalization (Benito and Welch, 1997; Onkelinx, Manolova, and Edelman, 2016) and reverse internationalization (Gnizy and Shoham, 2014). However, these studies did not qualify for this analysis because they did not include any correlation matrices or lacked suitable correlation matrices. Furthermore, the recent study by Arte and Larimo (2019) in the Appendix was not used as there were no correlation matrices and their tables indicated potential negative or positive relationships.

Specifically, the following six criteria were used to qualify a study and choose it for this analysis: initially, all the studies involved should indicate that the subsidiary divestment relates to 
a foreign target market. This point is important as there are different types of subsidiaries in the domestic and foreign market and therefore the study chooses subsidiaries in foreign markets. Therefore, the IJV or subsidiary divestments should relate to a foreign and not to the local target market. For instance, the paper by Baden-Fuller (1989) was not included in the analysis as the author was referring to exits of only British-owned manufacturers from the UK steel industry. Secondly, all studies should deal with foreign divestments, exits, divestitures, failures, survival, sell-offs, and other similar terminology. Thirdly, the study includes in the analysis studies related to IJVs and subsidiary divestments. As a fourth criterion, all the studies should have a correlation matrix including at least divestment, exit, divestiture, failure, survival, sell-off, closure, termination, or similar terminology as a dependent variable. A fifth criterion was whether the paper was published in business-related journals and conferences, working papers and unpublished Ph.D. theses provided at Google. Finally, the study provided a sixth criterion, which relates to clarifications regarding the reasoning for including or excluding some studies (see Appendix). For example, all three manuscripts by Belderbos and Zou, which are based on the same investigation in Japan but testing different models, are included. Furthermore, all four of Song's (2015, 2014a, 2014 b and 2014c) papers, which deal with two different studies and four different models, are included.

Four studies are excluded from the current analysis for various reasons, as follows: Li's (2008) study did not measure divestment or subsidiary divestment in his correlation matrix. Park and Russo's (1996) study was problematic, because their IJV failure was the only construct in their correlation matrix relevant to this study. Furthermore, Reuer and Tong's (2005) study examines the call option and was excluded from the analysis. Finally, Fischer and Pollock's (2004) study was not included in the analysis as it investigates IPO firm failure. 
The Appendix shows that there have been 80 studies on divestment/subsidiary exit that include a correlation matrix in their analysis, which is the fourth criterion mentioned above. However, there are other studies on divestment/subsidiary exit with correlation matrices which were excluded from Appendix that did not meet the six criteria. In total, Appendix includes 26 studies that investigate US firms, while 22 studies focus on Japanese firms, 9 on Korean firms, and 4 on German firms.

Most of the investigations are published in the Strategic Management Journal (19 studies), Journal of International Business Studies (8 studies), Academy of Management Journal (6 studies), and Management International Review (4 studies). The remaining 43 investigations are found in such journals as the Journal of Management (3 studies), Journal of World Business (3 studies), Journal of Business Research (3 studies), Asia Pacific Journal of Management (3 studies), Organization Science (2 studies), Global Strategy Journal (2 studies), International Business Review (2 studies), British Journal of Management (2 studies), Long Range Planning (1 study), The Economic Journal (1 study), Applied Economics (1 study), Transnational Corporations (1 study), International Studies of Management and Organization (1 study), International Journal of Industrial Organization (1 study), Journal of Economic Geography (1 study), Journal of Strategy and Management (1 study), Management Decision (1 study), Journal of Family Business Strategy (1 study), Journal of International Management (1 study), Asia Pacific Business Review (1 study), Journal of Business Economics (1 study), Thunderbird International Business Review (1 study), Journal of Business Theory and Practice (1 study), Journal of International Marketing (1 study), Managerial Decision Economics (1 study), $1 \mathrm{PhD}$ study, 3 working papers, and 1 conference paper. The Appendix reveals that the calculations of this study are based on 87 correlation matrices and 10877 observations or correlations. The construction of the Appendix helped us to gather 
correlations/data on the different relationships included in Table 1 and Table 2 (see section 4.1 below).

The 80 studies in the Appendix are divided into four categories (“A”; "B”; "C"; and "D”). Category "A" includes 42 studies whose correlation matrices indicate a relationship between divestment/subsidiary exit and performance/profitability/ROA; category "B" includes 22 studies that focus on divestment/subsidiary exit; category " $C$ " includes 10 studies that focus on performance/profitability/ROA ; and category " $\mathrm{D}$ " includes 6 studies that are not included in categories "A," "B," or “C."

It is evident from the Appendix that 42 studies (52.5\%) show the relationship between divestment/subsidiary exit and performance/profitability/ROA. Furthermore, 22 studies (27.5\%) show only divestment/ subsidiary exit as being related to other variables except performance. Finally, 10 studies (12.5\%) show that only performance/profitability/ROA is related to the other variables except divestment/subsidiary exit. The model of the current study (see Figure 1) shows all three possibilities. The third possibility is investigated here, showing that performance is related to the antecedents of divestment (see Figure 1).

Category "D" includes studies that focus on variables other than divestment/subsidiary exit and performance/profitability/ROA, which are correlated in the analyses.

\subsection{Method of collection of the studies and sample}

The studies were collected using five different databases such as EBSCO, ScienceDirect, Web of Science, Scopus, and Journal of Business Studies through membership of the Academy of 
International Business (AIB). The identification of the papers was achieved using two keywords, namely, divestment and subsidiary exit for all five databases.

Although the 87 correlation matrices consists of 10877 correlations, the multinomial logistic regression used to estimate the five models in Table 1 and the regression analysis for testing the moderating effects in Table 2 are based on considerably less than 10877 correlations, because the number of relationships taken from each correlation matrix is limited.

\subsection{Methods and variables used in this study}

First, we used multinomial logistic regression to examine the significance of the following independent parameters of the dependent variable of firm financial performance: R\&D intensity, per capita GDP, GDP growth rate, cultural distance, political risk, host market uncertainty/risk, international experience, host country-specific experience, divestiture experience, product and business relatedness/unrelatedness, parent size, parentage, subsidiary size, subsidiary age, acquisition, and IJV. Second, the study used regression analysis to test the moderating effects of advertising intensity and product diversification on firm financial performance.

Regarding the variables used in the analysis, the author included 22 variables with 48 observations. The 22 variables had different numbers of observations, ranging from 2 to 23 . Fifteen independent variables had 2 to 10 observations, while the rest of the 7 independent variables had 11 to 23 observations. For the first, second, and third models the dependent variables were, respectively, parent firm performance profitability, parent firm performance (profitability and parent ROA), and subsidiary performance (see Table 1).

\section{Results}




\subsection{Results related to the propositions}

Based on five types of financial performance, namely parent performance/profitability, ROS, parent ROA, subsidiary ROA and subsidiary performance, the study develops seven separate models (shown in Table 1) based on multinomial logistic regressions.

Please place Table 1 about here

The study uses multinomial logistic regressions because the performance variables are categorical. The first model shows five significant relationships, namely R\&D intensity to parent performance, international experience to parent performance, divestiture experience to parent performance, parent size to parent performance, and acquisition to parent performance. The second model supports seven relations: R\&D intensity to parent performance/ROA, international experience to parent performance/ROA, divestiture experience to parent performance/ROA, parent size to parent performance/ROA, subsidiary size to parent performance/ROA, subsidiary age to parent performance/ROA, and acquisition to parent performance/ROA. In the third model, there was no relationship supported by multinomial logistic regression, and subsidiary performance seems to have no value in the analysis. Analysis of Model 2 (the dependent variable of parent firm performance is measured by profitability and ROA), as shown in Table 1, reveals that the following propositions are supported: Propositions 1 (R\&D intensity), 3 (related to international experience and divestiture experience), 4 (related to parent size, subsidiary size, and subsidiary age), and 5 (related to acquisition). Conversely, Propositions 2, 3 (related to host country-specific experience), 4 (related to product and business relatedness/unrelatedness, and 
parentage), and 5 (related to IJV) are not supported. Model 1 is worse than Model 2, as it has more non-significant variables than Model 2, and finally, Model 3 has no significant variables.

\subsection{Moderating effects of advertising intensity and product diversification}

As detailed in Table 2 below, the study examines the moderating factors of advertising intensity and product diversification on the following relationships: a) the relationship of firm innovativeness to subsidiary divestment, b) the relationship of firm innovativeness to subsidiary divestment, c) the relationship of economic factors in the target country to subsidiary divestment, d) the relationship of environmental factors in the target country to subsidiary divestment, e) the relationship of type of experience to subsidiary divestment, f) the relationship of organizational characteristics to subsidiary divestment, g) the relationship of investment strategy to subsidiary divestment, and h) the moderating effect of advertising intensity and product diversification on firm financial performance.

Please place Table 2 about here

This analysis of moderating factors integrates the literature of 30 years (1989-2018) on subsidiary divestment, and provides the working relationships included in the 87 correlation matrices of the 80 papers examined. The sample size of 87 correlation matrices is not large; however, one can identify whether the moderating effects are statistically significant or not. Table 2 shows that only the advertising intensity effect is a significant weakening moderator on the relationship between organizational characteristics (OrCh) and subsidiary divestment (Perf) (see Figure 1). 
Furthermore, advertising intensity is a significant weakening moderator and product diversification a significant strengthening moderator on firm financial performance.

Considering that this paper is a review of the articles in the field of divestment (see Appendix), the results that are covered in the three pages including those showing Table 1 and Table 2, are considered sufficient. Furthermore, this study's conceptual model, as shown in Figure 1 , is completely different from other previous conceptual models, such as that of Arte and Larimo (2019) and Coudounaris (2017). Therefore, the current study adds value to the existing literature by investigating the relationships between antecedents and parent firm performance (Table 1), the moderating effects of advertising intensity and product diversification between the antecedents, and the parent firm performance related to subsidiary divestment (Table 2).

\section{Conclusion, implications, limitations, and future research}

\subsection{Conclusion}

This study aimed to identify existing relationships regarding the determinants that influence subsidiary divestment in the IB environment and find gaps in the subsidiary divestment/survival literature by performing multinomial logistic regression. It sheds light on various important relationships considered essential for developing models that incorporate parent firm factors, which, in turn, affect financial performance and, finally, subsidiary divestment. Examining the constructs of the models, one can conclude that many researchers have utilized the following constructs as the central and primary ones: parent firm innovativeness, parent firm financial performance, environmental factors in the target country, type of experience, organizational characteristics, and investment strategy, which are heavily used in the models explaining the behavior of subsidiary divestments developed by most researchers in the period from 1989 to 2018. 
Importantly, the results also reveal that the positive effects of firms' organizational characteristics on subsidiary divestment are stronger for firms that invest more in advertising. Moreover, product diversification is not a significant moderator between the antecedents and subsidiary divestment. This shows that implementation of the policy of diversification is not at all beneficial in averting subsidiary divestment. Finally, advertising intensity and product diversification are significant moderators (the former has a weakening effect, whereas the latter has a strengthening effect) on firm financial performance, indicating their direct effect on performance.

The contribution of this paper is mainly in the investigation of the six relationships of the determinants of divestment on parent firm performance using multinomial logistic regression. Another possible contribution of this study is that, driven by the long-lasting recessions that have seriously affected most European and Third World markets, there is now a compelling need to assist managers to look for the most important relationships to consider before implementing a divestment strategy.

\subsection{Implications, limitations, and future research}

With regard to theoretical implications, based on 28 studies focusing on parent firm financial performance, the current study finds that the following relationships are of importance: $R \& D$ intensity to parent financial performance, international experience to parent financial performance, divestiture experience to parent financial performance, parent size to parent financial performance, subsidiary size and age to parent financial performance, and acquisitions to parent financial performance. However, no significant relationship involving the above variables to subsidiary performance was found that would indicate that subsidiary performance plays the role of a moderator (Chung et al., 2013). Furthermore, environmental factors are not found to be significant 
when the relationship of parent financial performance to subsidiary divestment was the dependent variable.

As far as practical/policy implications are concerned, the researchers would like to stress that the development managers of parent firms should exhaust other alternative strategies rather than implementing divestments. Government officials should implement such policies to prevent exits of manufacturing settlements from their countries (Kogut and Kulatilaka, 1994). Apart from the above implications, the study offers implications for bankers and MNC development managers. Bankers should realize that it is very important for MNCs to relocate their factories in case of economic fluctuations in the Third World or to be aware of environmental changes in certain locations that could cause an increase in risk management and uncertainty. Furthermore, bankers should take into consideration the findings of Table 1, which clearly indicate some important relationships, namely $R \& D$ intensity to parent financial performance, experience (international experience and divestiture experience) to parent financial performance, organizational characteristics (parent size, parentage) to parent financial performance, and investment strategy (acquisition) to parent financial performance. These relationships are shown to be supported in 29 different studies, indicating their importance for bankers when evaluating MNCs in terms of providing financial assistance.

Additionally, MNC development managers should identify these seven factors that influence financial performance and use them as tools to avoid making rash decisions for divestment that may lead to losses of money and time to reallocate the investments. Finally, the implications regarding banking units could be, for example, the training of their staff to be more positive towards subsidiary exits. 
In terms of the interpretation of the weakening effect of advertising intensity on the relationship between organizational characteristics and subsidiary divestment, one can say that the increase of advertising campaigns may weaken the subsidiary divestment, especially for older, larger subsidiaries. Furthermore, advertising intensity and product diversification can have weakening and strengthening effects on the firm financial performance of the headquarters, thus eliminating or boosting the threat of subsidiary divestment, respectively.

Regarding the limitations of this study, one can argue that there were no structural equation modeling (SEM) analyses in the studies examined by this review with similar sets of variables. Furthermore, in the previous studies examined by this review, no betas were found between the latent constructs and subsidiary divestment, as well as the means and standard errors of the latent variables. Another limitation of this study is that it was impossible to find the effect of financial performance on subsidiary divestment, as the latter construct is a binary one and there were no observations about subsidiary divestment because the analysis of moderators is based on correlation data. Finally, the causality of organizational characteristics to subsidiary divestment and, of course, the causality of the rest of the antecedent factors to subsidiary divestment are not clear as there has been no SEM analysis in this field of studies. However, a future empirical study could resolve the issue of causality.

Future researchers should use the outcomes of this analysis on subsidiary divestment, that is to say, they should empirically test the seven relationships of $R \& D$ intensity, international experience, divestiture experience, parent size, subsidiary size, subsidiary age, and acquisitions all related to financial performance, and the eleven important relationships which are completely different from those found in another study (based on meta-analytic correlations: Coudounaris, 2017; see note below). Furthermore, a future study should deal with the effect of both the financial 
performance and the market performance on subsidiary divestment, as well as which factors influence divestitures in advanced, developing, and less developed countries, by conducting interviews with subsidiary managers. Additionally, other factors should be investigated in addition to advertising intensity and product diversification, which moderate the relationship between determinants of divestment and parent firm performance.

Finally, future research should investigate the relationship risk of CEOs who take the final decision to divest and what the prominent reasons or factors are that play a decisive role in their decision of whether to divest or not, based on, for example, interpersonal or environmental reasons.

Endnote: The authors considered it of importance to emphasize Coudounaris' (2017) findings to show that this study and its conceptual model investigate the relationships of the antecedents to the parent firm performance, which in turn influence subsidiary divestment. Therefore, the explanation of the value of the current study is related to previous studies' findings and helps, to some extent, to understand what the novelty of this study is.

Coudounaris (2017) finds the following eleven relationships to be important in a recent meta-analysis on subsidiary exit: 1) parent firm patent intensity linked to parent firm size, 2) diversification associated with international experience (including parent firm and prior experience), 3) diversification linked to divestiture experience, 4) diversification associated with parent firm size, 5) decrease of per capita GDP linked to political risk, 6) decrease of GDP growth rate associated with subsidiary age, 7) international experience linked to host country-specific experience, 8) host country-specific experience associated with parent firm size, 9) international experience linked to parent firm size, 10) international experience associated with parent firm age, and 11) relatedness linked to parent firm age. 


\section{References}

Anand, J., Mesquita, L., and Vassolo, R. (2009). The dynamics of multimarket competition in exploration and exploitation activities. Academy of Management Journal, 52(4), 802-821.

Andersson, U., Forsgren, M., and Holm, U. (2002). The strategic impact of external networks: Subsidiary performance and competence development in the multinational corporation. Strategic Management Journal, 23(11).

Arte, P., and Larimo, J. (2019). Taking stock of foreign divestment: Insights and recommendations from three decades of contemporary literature. International Business Review, 28(6).

Baden-Fuller, C. (1989). Exit from declining industries and the case of steel castings. The Economic Journal, 99, 949-961.

Barney, J.B. (1991). Firm resources and sustained competitive advantage. Journal of Management, 17, 99-120.

Barney, J.B. (2001). Is the resource-based view a useful perspective for strategic management research? Yes. Academy of Management Review, 26, 41-54.

Barney, J.B., Wright, M., and Ketchen, D.J. (2001). The resource-based view of the firm: Ten years after 1991. Journal of Management, 27, 625-643.

Barney, J.B., Ketchen Jr., D.J., and Wright M. (2011). The future of resource-based theory: Revitalization or decline? Journal of Management, 37(5), 1299-1315.

Belderbos, R., and Zou, J. (2006). Divestment of foreign manufacturing affiliates: Country platforms, multinational plant networks, and foreign investor agglomeration. Department of Managerial Economics, Strategy and Innovation, Catholic University of Leuven, file://C:/Users/dcoudoun/Downloads/SSRN-id944741.pdf

Belderbos, R., and Zou, J. (2007). On the growth of foreign affiliates: Multinational plant networks, joint ventures, and flexibility. Journal of International Business Studies, 38, 10951112.

Belderbos, R., and Zou, J. (2009). Real options and foreign affiliate divestments: A portfolio perspective. Journal of International Business Studies, 40, 570-620.

Benavides-Espinosa, M.M., and Roig-Dobón, S. (2011). The influence of cultural differences in cooperative learning through joint ventures. Service Business, 5(1), 69-85.

Benito, G. (1997a). Why are foreign subsidiaries divested? A conceptual framework. In I. Björkman and M. Forsgren (eds), The Nature of the International Firm, pp. 309-334. Copenhagen: Copenhagen Business School Press.

Benito, G. R. G. (1997b). Divestment of foreign production operations. Applied Economics, 29, 1365-1377.

Benito, G. (2005). Divestment and international business strategy. Journal of Economic Geography, 5(2), 235-251.

Benito, G. R. G., and Welch, L. S. (1997). De-internationalization. Management International Review, 37(2), 7-25.

Bergh, D. (1997). Predicting divestiture of unrelated acquisitions: An integrative model of ex-ante conditions. Strategic Management Journal, 18(9), 715-31.

Berry, H. (2004). Corporate divestment: The influence of foreign investment strategies. 
Working Paper at The Warton School, Department of Management, University of Pennsylvania.

Berry, H. (2010). Why do firms divest? Organization Science, 21(2), 380-396.

Berry, H. (2013). When do firms divest foreign operations? Organization Science, 24(1), 246261.

Boddewyn, J., and Torneden, R. (1973). U.S. foreign divestment: A preliminary survey. Journal of World Business, Summer, 25-29.

Boddewyn, J. (1979). Foreign divestment: Magnitude and factors. Journal of International Business Studies, Spring, 21-27.

Boddewyn, J. (1983). Foreign direct divestment theory: Is it the reverse of FDI theory? Review of World Economics, 119(2), 345-355.

Brauer, M., and Schimmer, M. (2010). Performance effects of corporate divestiture programs. Journal of Strategy and Management, 3(2), 84-109.

Brauer, M., and Wiersema, M. (2012). Industry divestiture waves: How a firm's position influences investor returns. Academy of Management Journal, 55(6), 1472-1492.

Brooke, M., and Remmers, H. (1977). The International Firm. Pitman Publishing Ltd, London, UK.

Cantwell, J. and Mudambi, R. (2005). MNE competence-creating subsidiary mandates. Strategic Management Journal, 26(12), 1109-1128.

Caves, R. (1995). Growth and decline in multinational enterprises: From equilibrium models to turnover processes. In Chen EKY, Drysdale P. (Eds), Corporate Links and Foreign Direct Investment in Asia and the Pacific, pp. 9-28.

Chan, C., Makino, S., and Isobe, T. (2006). Interdependent behavior in foreign direct investment: The multi-level effects of prior entry and prior exit on foreign market entry. Journal of International Business Studies, 37, 612-665.

Chang, S. J., and Singh, H. (1999). The impact of modes of entry and resource fit on modes of exit by multibusiness firms. Strategic Management Journal, 20, 1019-1035.

Chung, C., Lee, S-H, and Lee J-Y. (2013a). Dual-option subsidiaries and exit decisions during times of economic crisis. Management International Review, 53, 555-577.

Chung, C., Lee, S-H, Beamish, P., Southam, C., and Nam, D. (2013). Pitting real options theory against risk diversification theory: International diversification and joint ownership control in economic crisis. Journal of World Business, 48, 122-136.

Coucke, K., and Sleuwaegen, L. (2008). Offshoring as a survival strategy: Evidence from manufacturing firms in Belgium. Journal of International Business Studies, 19, 1261-1277.

Coudounaris, D. N. (2017). A meta-analysis on subsidiary divestment. In Stieler M. (ed.), Creating Marketing Magic and Innovative Future Marketing Trends, pp. 837-860. Publisher: Springer.

Cui, A., and Kumar, M. (2012). Termination of related and unrelated joint ventures: A contingency approach. Journal of Business Research, 65(8), 1202-1208.

Dai, L., Eden, L., and Beamish, P. (2013). Place, space, and geographical exposure: Foreign subsidiary survival in conflict zones. Journal of International Business Studies, 44, 554-578.

Dai, L., Eden, L., and Beamish, P. W. (2017). Caught in the crossfire: Dimensions of vulnerability and foreign multinationals' exit from war-afflicted countries. Strategic Management Journal, 38, 1478-1498. 
Damaraju, N., Barney, J., and Makhija, A. (2015). Real options in divestment alternatives. Strategic Management Journal, 36, 728-744.

Decker, C., and Mellewigt, T. (2012). Business exit and strategic change: Sticking to the knitting or striking a new path? British Journal of Management, 23, 165-178.

Delios, A., and Beamish, P. (2001). Survival and profitability: The roles of experience and intangible assets in foreign subsidiary performance. Academy of Management Journal, 44(5), 1028-1038.

Delios, A., Xu, D., and Beamish, P. (2008). Within-country product diversification and foreign subsidiary performance. Journal of International Business Studies, 39, 706-724.

Demirbag, M., Apaydin, M., and Tatoglu, E. (2011). Survival of Japanese subsidiaries in the Middle East and North Africa. Journal of World Business, 46, 411-425.

Doole, I., Lowe, R., and Kenyon, A. (2016). International Marketing Strategy-Analysis, Development and Implementation. 7th Edition. Cengage Learning EMEA, Hampshire, UK.

Duhaime, I. M., and Grant, J. H. (1984). Factors influencing divestment decision-making: evidence from a field study. Strategic Management Journal, 5(4), 301-318.

Durand, R., and Vergne, J-P. (2014). Asset divestment as a response to media attacks in stigmatized industries. Strategic Management Journal, 36(8), 1205-1223.

Elfenbein, D., and Knott, A. (2014). Time to exit: Rational, behavioural, and organizational delays. Strategic Management Journal, 36(7), 957-975.

Ewelt-Knauer, C., Knauer, T., and Thielemann, M. (2014). Exit behaviour of investment companies: The choice of exit channel. Journal of Business Economics, 84, 571-607.

Farah, B. (2014). Multinational Enterprise Parent-Foreign Subsidiary Governance. Western University. Unpublished PhD supervised by Professor P. W. Beamish.

Fisch, J. H., and Zschoche, M. (2012). The effect of operational flexibility on decisions to withdraw from foreign production locations. International Business Review, 21, 806-816.

Fischer, H., and Pollock, T. (2004). Effects of social capital and power on surviving transformational change: The case of initial public offerings. Academy of Management Journal, 47(4), 463-481.

Gaur, A., and Lu, J. (2007). Ownership strategies and survival of foreign subsidiaries: Impacts of institutional distance and experience. Journal of Management, 33(1), 84-110.

Getachew, Y., and Beamish, P. W. (2017). Foreign subsidiary exit from Africa: The effects of investment purpose diversity and orientation. Global Strategy Journal, 7, 58-82.

Gnizy, I., and Shoham, A. (2014). Explicating the reverse internationalization processes of firms, Journal of Global Marketing, 27(4), 262-283

Goldratt, E., and Cox, J. (1984). The Goal: A Process of Ongoing Improvement. North River Press, Croton-on-Hudson, New York.

Gu, W., Qian, X. and Lu, J. (2018). Venture capital and entrepreneurship: A conceptual model and research suggestions. International Entrepreneurship and Management Journal, 14(1), $35-50$.

Haynes, M., Thompson, S., and Wright, M. (2000). The determinants of corporate divestment inthe UK. International Journal of Industrial Organization, 18, 1201-1222.

Haynes, M., Thompson, S., and Wright, M. (2002). The impact of divestment on firm performance: Empirical evidence from a panel of UK companies. The Journal of Industrial Economics, L(2), 173-196. 
Haynes, M., Thompson, S., and Wright, M. (2003). The determinants of corporate divestment: Evidence from a panel of UK firms. Journal of Economic Behavior and Organization, 52, 147-166.

Hayward, M., and Shimizu, K. (2006). De-commitment to losing strategic action: Evidence from the divestiture of poorly performing acquisitions. Strategic Management Journal, 27, 541-557.

Hitt, M.A., Tihanyi, L., Miller, T., and Connelly, B. (2006). International diversification: Antecedents, outcomes, and moderators. Journal of Management, 32(6), 831-867.

Hoskisson, R., Johnson, R., and Moesel, D. (1994). Corporate divestiture intensity in restructuring firms: Effects of governance, strategy, and performance. Academy of Management Journal, 37(5), 1207-1251.

Hutzschenreuter, T., Kleindienst, I., and Greger, C. (2018). Seeking distinctiveness through divestments: CEO succession and the effect of demographic similarity on the divestment of predecessor's investments. Managerial Decision Economics, 39, 462-474.

Hwang, P. (2005). Managing bond: An integrative approach. The Journal of Business, 78(2), 557-576.

Hwang, P. (2006). Asset specificity and the fear of exploitation. Journal of Economic Behavior \& Organization, 60, 423-438

Jung, H., Hwang, J., \& Kim, B. K. (2018). Does R\&D investment increase SME survival during a recession?. Technological Forecasting and Social Change, 137, 190-198.

Kang, J., Lee, J. Y., and Ghauri, P. N. (2017). The interplay of Mahalanobis Distance and firm capabilities on MNC subsidiary exits from host countries. Management of International Review, 57, 379-409.

Kaul, A., Nary, P., and Singh, H. (2018). Who does private equity buy? Evidence on the role of private equity from buyouts of divested businesses. Strategic Management Journal, 39, 12681298.

Keomixaya, B., and Ngamkroeckjoti, C. (2011). Factors affecting foreign direct investment in Savannakhet Province, Lao People's Democratic Republic (Lao PDR). Proceedings of International Conference on Management Economics and Social Sciences (ICMESS2011), Bangkok, 572-575, https:// psrcentre.org/images/extraimages/16.\%201211827.pdf

Kim, T-Y., Delios, A., and Xu, D. (2010). Organizational geography, experiential learning and subsidiary divestment: Japanese foreign expansions in China, 1979-2001. Journal of Economic Geography, 10, 579-597.

Kim, Y-C., Lu, J. W., and Rhee, M. (2012). Learning from age difference: Interorganizational learning and survival in Japanese foreign subsidiaries. Journal of International Business Studies, 43, 719-745.

Kogut, B. and Kulatilaka, N. (1994). Operating flexibility, global manufacturing, and the option value of a multinational network. Management Science, 40(1), 123-139.

Lee, D., and Madhavan, R. (2010). Divestiture and firm performance: A meta-analysis. Journal of Management, 36(6), 1345-1371.

Lee, G., Folta, T., and Lieberman, M. (2010). Relatedness and market exit. In Academy of Management Proceedings (Vol. 2010, No. 1, pp. 1-6). Briarcliff Manor, NY 10510: Academy of Management. 
Leonidou, L.C., Katsikeas, C. S., and Samiee, S. (2002). Marketing strategy determinants of export performance: A meta-analysis. Journal of Business Research, 55(1), 51- 67

Li, J. (1995). Foreign entry and survival: Effects of strategic choices on performance in international markets. Strategic Management Journal, 16(5), 333-351.

Li, R., and Liu, Z. (2015). What causes the divestment of multinational companies in China? A subsidiary perspective. Journal of Business Theory and Practice, 3(1), 81-89.

Li, Y. (2008). Duration analysis of venture capital staging: A real options perspective. Journal of Business Venturing, 23(5), 497-512.

Lu, J., and Hébert, L. (2005). Equity control and the survival of international joint ventures: A contingency approach. Journal of Business Research, 58, 736-45.

$\mathrm{Lu}, \mathrm{J}$, and $\mathrm{Xu}, \mathrm{D}$. (2006). Growth and survival of international joint ventures: An externalinternal legitimacy perspective. Journal of Management, 32(3), 426-48.

Makino, S, Chan, C., Isobe, T., and Beamish, P. (2007). Intended and unintended termination of international joint venture. Strategic Management Journal, 28, 1113-1132.

Malik, T. H. (2018). Defence investment and the transformation national science and technology:

A perspective on the exploitation of high technology. Technological Forecasting and Social Change, 127, 199-208.

Markides, C. (1995). Diversification, restructuring and economic performance. Strategic Management Journal, 16, 101-118.

Mariotti, S., and Piscitello, L. (1999). Is divestment a failure or part of a restructuring strategy? The case of Italian transnational corporations. Transnational Corporations, 8(3), 25-51.

Mata, J. and Freitas, E. (2012). Foreignness and exit over the life cycle of firms. Journal of International Business Studies, 43(7), 615-630.

Mata, J., and Portugal, P. (2000). Closure and divestment by foreign entrants: The impact of entry and post-entry strategies. Strategic Management Journal, 21, 549-562.

Meschi, P-X., and Métais, E. (2015). Too big to learn: The effects of major acquisition failures on subsequent acquisition divestment. British Journal of Management, 26, 408-423.

Minbaeva, D., Pedersen, T., Bjorkman, I., Fey, C.F. and Park, H.J. (2003). MNC knowledge transfer, subsidiary absorptive capacity, and HRM. Journal of International Business Studies, 34(6), 586-599.

Mohr, A., Batsakis, G., and Stone, Z. (2018). Explaining the effect of rapid internationalization on horizontal foreign divestment in the retail sector: An extended Penrosean perspective. Journal of International Business Studies, 49, 779-808.

Moliterno, T., and Wiersema, M. (2007). Firm performance, rent appropriation, and the strategic resource divestment capability. Strategic Management Journal, 28, 1065-1087.

Moschieri, C. and Mair, J. (2008). Research on corporate divestitures: A synthesis. Journal of Management \& Organization, 14(4), 399-422.

Mudambi, R. and Navarra, P. (2004). Is knowledge power? Knowledge flows, subsidiary power and rent-seeking within MNCs. Journal of International Business Studies, 35(5), 385-406.

Nijs, V. R., Dekimpe, M. G., Steenkamp, J-B. E.M., and Hanssens, D. M. (2001). The categorydemand effects of price promotions. Marketing Science, 20(1), 1-22.

Nyuur, R. B., and Debrah, Y. A. (2014). Predicting foreign firms' expansion and divestment intentions in host countries: Insights from Ghana. Thunderbird International Business Review, 56(5), 407-419. 
Onkelinx, J., Manolova, T.S., and Edelman, L.F. (2016). The consequences of deinternationalization: Empirical evidence from Belgium. In Global Entrepreneurship: Past, Present and Future, Advances in International Management, 29, 45-66.

Park, R., Lee, J. Y., and Hong, S. (2011). Effects of international entry-order strategies on foreign subsidiary exit: The case of Korean chaebols. Management Decision, 49(9), 14711488.

Park, S., and Russo, M. (1996). When competition eclipses cooperation: An event history analysis of joint venture failure. Management Science, 42(6), 875-890.

Park, S., and Ungson, G. (1997). The effect of national culture, organizational, complementarity, and economic motivation on joint venture dissolution. Academy of Management Journal, 40(2), 279-307.

Park, Y-R., and Park, S-W. (1999). Determinants of FDI survival: The case of Korean manufacturing firms. In AIB conference in Phoenix, Arizona.

https://gebrc.nccu.edu.tw/proceedings/APDSI/2000/list/pdf/P-121.PDF

Pathak, S., Hoskisson, R., and Johnson, R. (2014). Settling up in CEO compensation: The impact of divestiture intensity and contextual factors in refocusing firms. Strategic Management Journal, 35, 1124-1143.

Pattnaik, C., and Lee, J. (2014). Distance and divestment of Korean MNC affiliates: The moderating role of entry mode and experience. Asia Pacific Business Review, 20(1), 174-196.

Peng, G., and Beamish, P. (2014). The effect of host country long term orientation on subsidiary ownership and survival. Asia Pacific Journal of Management, 31, 423-453.

Pérez, J. A. H., Kunc, M. H., Durst, S., Flores, A., \& Geldes, C. (2018). Impact of competition from unregistered firms on R\&D investment by industrial sectors in emerging economies. Technological Forecasting and Social Change, 133, 179-189.

Polidoro, F., Ahuja, G., and Mitchell, W. (2011). When the social structure overshadows competitive incentives: The effects of network embeddedness on joint venture dissolution. Academy of Marketing Journal, 54(1), 203-223.

Pot, W. D., Dewulf, A., Biesbroek, G. R., Van der Vlist, M. J., \& Termeer, C. J. A. M. (2018). What makes long-term investment decisions forward looking: A framework applied to the case of Amsterdam's new sea lock. Technological Forecasting and Social Change, 132, 174-190.

Praet, A. (2013). Family firms and the divestment decision: An agency perspective. Journal of Family Business Strategy, 4, 34-41.

Procher, V. D., and Engel, D. (2018). The investment-divestment relationship: Resource shifts and intersubsidiary competition within MNEs. International Business Review, 27, 528-542.

Rapoport, A. (1967). A note on the "index of cooperation" for prisoner's dilemma. Journal of Conflict Resolution, 11, 101-103.

Rapoport, A., and Chammah, A.M. (1965). Prisoner's Dilemma. Ann Arbor, MI: University of Michigan University Press.

Reuer, J., and Tong, T. (2005). Real options in international joint ventures. Journal of Management, 31(3), 403-423.

Rugman, A., and Brewer, T. (2001). The Oxford Handbook of International Business. Oxford: Oxford University Press.

Sachdev, J. (1976). A framework for the planning of disinvestment policies for multinational 
companies. PhD thesis, International Business Unit, University of Manchester Institute of Science and Technology.

Sarkar, M., Echambadi, R., Agarwal, R., and Sen, B. (2006). The effect of the innovative environment on exit of entrepreneurial firms. Strategic Management Journal, 27, 519-539.

Shaver, J., Mitchell, W., and Yeung, B. (1997). The effect of own-firm and other-firm experience on foreign direct investment survival in the United States, 1987-92. Strategic Management Journal, 18(10), 811-824.

Shimizu, K., and Hitt, M. (2005). What constrains or facilitates divestitures of formerly acquired firms? The effects of organizational inertia. Journal of Management, 31(1), 50-72.

Song, S. (2014a). Subsidiary divestment: the role of multinational flexibility. Management International Review, 54, 47-70.

Song, S. (2014b). Entry mode irreversibility, host market uncertainty, and foreign subsidiary divestments. Asia Pacific Journal of Management, 31, 455-471.

Song, S. (2014c). Unfavorable market conditions, institutional and financial development, and divestments of foreign subsidiaries. Journal of International Management, 20, 279-289.

Song, S. (2015). Exchange rate challenges, flexible intra-firm adjustments, and subsidiary longevity. Journal of World Business, 50, 36-45.

Song, S., and Lee, J. Y. (2017). Relationship with headquarters and divestments of foreign subsidiaries: The hysteresis perspective. Management International Review, 57, 545-570.

Soule, S. A., Swaminathan, A., and Tihanyi, L. (2014). The diffusion of foreign divestment from Burma. Strategic Management Journal, 35, 1032-1052.

Sousa, C. M. P., and Tan, Q. (2015). Exit from a foreign market: Do poor performance, strategic fit, cultural distance, and international experience matter? Journal of International Marketing, 23(4), 84-104.

Steensma, H., and Lyles, M. (2000). Explaining IJV survival in a transitional economy through social exchange and knowledge-based perspectives. Strategic Management Journal, 21, 831-851.

Tan, Q., and Sousa, C. M. P. (2017). Performance and business relatedness as drivers of exit decision: A study of MNCs from an emerging country. Global Strategy Journal, 1-23

Van Kranenburg, H., Cloodt, M., and Hagedoorn, J. (2001). An exploratory study of recent trends in the diversification of Dutch publishing companies in the multimedia and information industries. International Studies of Management and Organization, 31(1), 64-86.

Wang, Y., and Larimo, J. (2015). Impact of ownership level on subsidiary survival in foreign acquisitions, $13^{\text {th }}$ IB Vaasa Conference, 27-28 August.

Williamson, O. E (1975). Markets and Hierarchies: Analysis and Antitrust Implications. New York: Free Press.

Williamson, O. E. (1985). The Economic Institutions of Capitalism. Free Press, New York.

Wu, J., Xu, D., and Phan, P. (2011). The effects of ownership concentration and corporate debt on corporate divestitures in Chinese listed firms. Asia Pacific Journal of Management, 28, 95-114.

Xia, J., and Li, S. (2013). The divestiture of acquired subunits: A resource dependence approach. Strategic Management Journal, 34, 131-148.

$\mathrm{Xu}, \mathrm{D}$., and Lu, J. W. (2007). Technological knowledge, product relatedness, and parent control: The effect on IJV survival. Journal of Business Research, 57, 1166-1176. 
Zschoche, M. (2016). Performance effect of divesting foreign production affiliates: A network perspective. Long Range Planning, 49, 196-206.

Please place Appendix about here

\section{FIGURE}

Antecedents*

Moderators Central Construct

Outcome

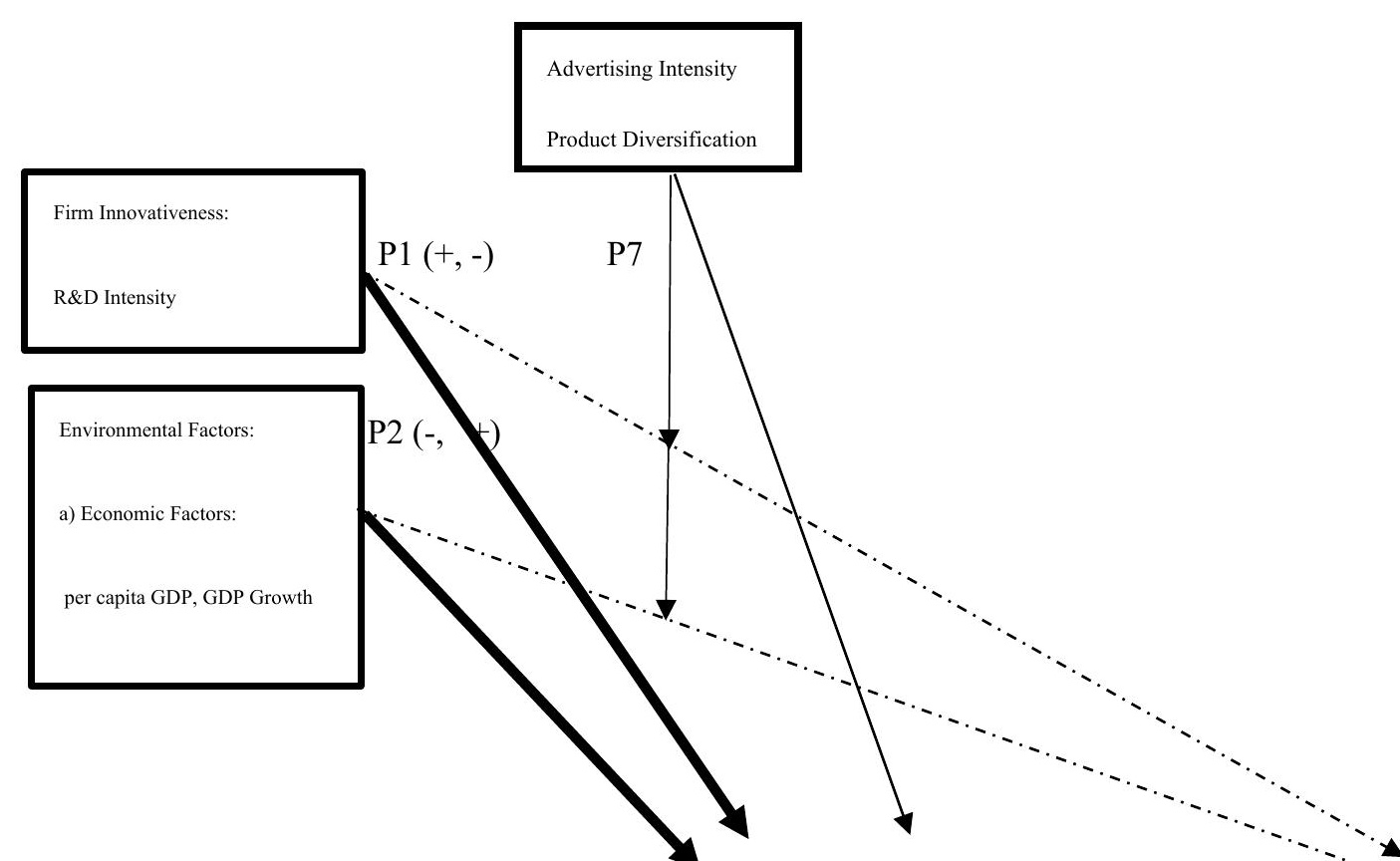




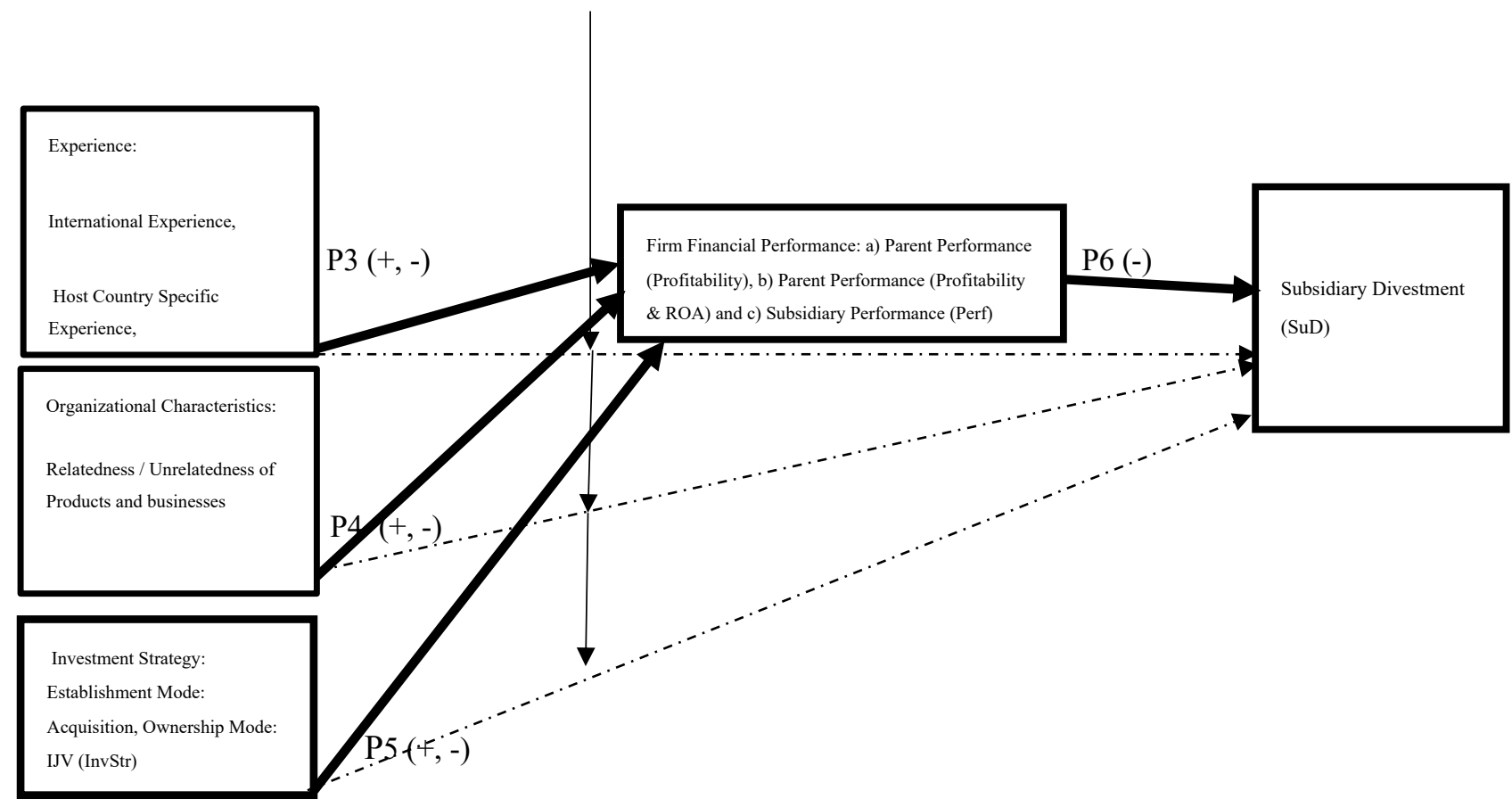

Note: *The expected impact is indicated in parentheses $(+,-)$.

Figure 1. Conceptual model: Antecedents and moderators of divestitures of foreign subsidiaries

\section{TABLES AND APPENDIX}

\section{TABLES}

Table 1. Analysis of three models and their relationships

\begin{tabular}{lllll}
\hline $\begin{array}{l}\text { Propo- } \\
\text { sitions }\end{array}$ & Variables & $\begin{array}{l}\text { Dependent: Parent } \\
\text { performance } \\
\text { (profitability)*, } \\
\text { Cox and Snell=.993, } \\
29 \text { cases/studies, }\end{array}$ & $\begin{array}{l}\text { Dependent: Parent } \\
\text { performance } \\
\text { (profitability and } \\
\text { parent ROA)*, Cox } \\
\text { and Snell=.994, }\end{array}$ & $\begin{array}{l}\text { Dependent: } \\
\text { Subsidiary } \\
\text { performance* } \\
\text { Cox and } \\
\text { Snell=.955, } \\
8 \text { cases/studies, }\end{array}$ \\
& Model 1 & $\begin{array}{l}\text { cases/studies, } \\
\text { Model 2 }\end{array}$ & Model 3 \\
\hline P1 & R\&D Intensity & S & S & NS \\
P2 & Per capita GDP & NS & NS & NS \\
P2 & GDP growth rate & NS & NS & NS \\
P2 & Cultural distance & NS & NS & NS \\
P2 & Political risk & NS & NS & NS \\
P2 & Host market uncertainty /risk & NS & NS & NS
\end{tabular}




$\begin{array}{llccc}\text { P3 } & \text { International experience } & \text { S } & \text { S } & \text { NS } \\ \text { P3 } & \text { Host country specific experience } & \text { NS } & \text { NS } & \text { NS } \\ \text { P3 } & \text { Divestiture experience } & \text { S } & \text { S } & \text { NS } \\ \text { P4 } & \text { Product and business } & \text { NS } & \text { NS } & \text { NS } \\ & \text { relatedness/unrelatedness } & & \text { S } & \text { NS } \\ \text { P4 } & \text { Parent size } & \text { S } & \text { NS } & \text { NS } \\ \text { P4 } & \text { Parent age } & \text { NS } & \text { S } & \text { NS } \\ \text { P4 } & \text { Subsidiary size } & \text { NS } & \text { S } & \text { NS } \\ \text { P4 } & \text { Subsidiary age } & \text { NS } & \text { S } & \text { NS } \\ \text { P5 } & \text { Acquisition } & \text { S } & \text { NS } & \text { NS } \\ \text { P5 } & \text { IJV } & \text { NS } & \text { NS }\end{array}$

Notes: $* \mathrm{~S}=$ Supported by multinomial logistic regression, $\mathrm{NS}=$ Non-supported by multinomial logistic regression. In 35 cases there is no measurement of either parent or subsidiary performance (see Appendix).

Table 2. Test of moderating factors: Advertising intensity and product diversification on the relationship between antecedents and firm financial performance/subsidiary divestment

\begin{tabular}{lccclllll}
\hline \multicolumn{3}{l}{ Moderating factor: Advertising Intensity } & \multicolumn{5}{l}{ Moderating factor: Product Diversification } \\
Variable & Beta & $\mathrm{t}$-values & $\mathrm{p}$-values & Variable & Beta & $\mathrm{t}$-values & $\mathrm{p}$-values \\
& & & & & & & \\
\hline ADInnov & -.030 & -.218 & .828 & DivInnov & -.016 & -.100 & .920 \\
ADFinan & $\mathbf{- . 5 0 9}$ & $\mathbf{- 4 . 4 6 3}$ & $\mathbf{. 0 0 0}$ & DivFinan & $\mathbf{. 3 3 1}$ & $\mathbf{2 . 6 4 8}$ & $\mathbf{. 0 1 0}$ \\
ADEcon & -.021 & -.158 & .875 & DivEcon & -.008 & -.050 & .957 \\
ADEnviron & -.001 & -.006 & .995 & DivEnviron & .006 & .034 & .973 \\
ADExp & -.018 & -.102 & .919 & DivExp & .018 & .082 & .935 \\
ADOrCh & -.255 & $\mathbf{- 1 . 7 4 5}$ & $\mathbf{. 0 8 6}$ & DivOrCh & .201 & 1.408 & .165 \\
ADInvStr & -.009 & -.057 & .953 & ADInvStr & -.001 & -.008 & .994
\end{tabular}

Appendix. Profiles of 80 empirical studies (1989 to 2018) on subsidiary divestment*

\begin{tabular}{|l|l|l|l|l|l|l|}
\hline N & Authors' names & $\begin{array}{l}\text { Name of } \\
\text { publication }\end{array}$ & $\begin{array}{l}\text { Origin of MNEs and } \\
\text { other firms }\end{array}$ & $\begin{array}{l}\text { Number of correlations } \\
\text { and Number of } \\
\text { correlation matrices } \\
\text { C.M.** }\end{array}$ & Sample size & $\begin{array}{l}\text { Home } \\
\text { country(ies) }\end{array}$ \\
\hline 1 & $\begin{array}{l}\text { Procher \& Engel } \\
(2018)\end{array}$ & $\begin{array}{l}\text { International } \\
\text { Business } \\
\text { Review }\end{array}$ & 3524 French MNEs & $\begin{array}{l}\text { 276, 1 C.M., divest } \\
\text { foreign, divest domestic; } \\
\text { "D" category; }\end{array}$ & 3524 & France \\
\hline 2 & $\begin{array}{l}\text { Hutzschenreuter, } \\
\text { Kleindienst \& } \\
\text { Greger (2018) }\end{array}$ & $\begin{array}{l}\text { Managerial } \\
\text { Decision } \\
\text { Economics }\end{array}$ & $\begin{array}{l}\text { Firms listed in HDAX } \\
\text { of German stock } \\
\text { exchange }\end{array}$ & $\begin{array}{l}153,1 \text { C.M., investment } \\
\text { reversal, divestment rate, } \\
\text { ROA; "C" category; }\end{array}$ & 77 firms & n.a. \\
\hline 4 & $\begin{array}{l}\text { Kaul, Nary \& } \\
\text { Singh (2018) }\end{array}$ & $\begin{array}{l}\text { Strategic } \\
\text { Management } \\
\text { Journal }\end{array}$ & $\begin{array}{l}\text { US manufacturing } \\
\text { firms }\end{array}$ & $\begin{array}{l}\text { 276, C.M., parent } \\
\text { operating return, parent } \\
\text { diversification } \\
\text { "A" category; }\end{array}$ & 1711 divestments & USA \\
\hline
\end{tabular}




\begin{tabular}{|c|c|c|c|c|c|c|}
\hline 5 & $\begin{array}{l}\text { Mohr, Batsakis, } \\
\text { \& Stone (2018) }\end{array}$ & $\begin{array}{l}\text { Journal of } \\
\text { International } \\
\text { Business } \\
\text { Studies }\end{array}$ & Global retailers & $\begin{array}{l}\text { 351, 1 C.M., foreign } \\
\text { divestment, performance, } \\
\text { product diversification; } \\
\text { "B + C" category; }\end{array}$ & $\begin{array}{l}\text { Planet Retail's top } \\
\text { global } 250 \\
\text { retailers in } 2012, \\
\text { Deloitte's top } 250 \\
\text { retailers } 2011 \text { and } \\
\text { UNCTAD'S top } \\
100 \text { TCs }\end{array}$ & $\begin{array}{l}211 \\
\text { countries }\end{array}$ \\
\hline 6 & $\begin{array}{l}\text { Song \& Lee* } \\
\text { (2017) }\end{array}$ & $\begin{array}{l}\text { Management } \\
\text { International } \\
\text { Review }\end{array}$ & 439 Korean MNCs & $\begin{array}{l}\text { 210, } 1 \text { C.M., subsidiary } \\
\text { exit, subsidiary ROA; } \\
\text { "C" category; }\end{array}$ & $\begin{array}{l}583 \text { out of } 5306 \\
\text { foreign production } \\
\text { subsidiaries have } \\
\text { divested }\end{array}$ & Korea \\
\hline 7 & $\begin{array}{l}\text { Kang, Lee \& } \\
\text { Ghauri (2017) }\end{array}$ & $\begin{array}{l}\text { Management } \\
\text { International } \\
\text { Review }\end{array}$ & Korean MNC's & $\begin{array}{l}\text { 276, 1 C.M., host country } \\
\text { exit, parent firm ROA, } \\
\text { subsidiary ROA; } \\
\text { "A" category; }\end{array}$ & & Korea \\
\hline 8 & $\begin{array}{l}\text { Tan \& Sousa } \\
(2018)\end{array}$ & $\begin{array}{l}\text { Global } \\
\text { Strategy } \\
\text { Journal }\end{array}$ & China & $\begin{array}{l}\text { 276, } 1 \text { C.M., exit, } \\
\text { international performance; } \\
\text { "A" category; }\end{array}$ & 180 firms & China \\
\hline 9 & $\begin{array}{l}\text { Dai, Eden \& } \\
\text { Beamish (2017) }\end{array}$ & $\begin{array}{l}\text { Strategic } \\
\text { Management } \\
\text { Journal }\end{array}$ & $\begin{array}{l}20 \text { war-afflicted } \\
\text { countries }\end{array}$ & $\begin{array}{l}\text { 105, } 1 \text { C.M., peer exits, } \\
\text { financial loss; } \\
\text { "A" category; }\end{array}$ & $\begin{array}{l}1162 \text { MNEs } \\
\text { subsidiaries }\end{array}$ & $\begin{array}{l}20 \text { war- } \\
\text { afflicted } \\
\text { countries }\end{array}$ \\
\hline 10 & $\begin{array}{l}\text { Getachew \& } \\
\text { Beamish (2017) }\end{array}$ & $\begin{array}{l}\text { Global } \\
\text { Strategy } \\
\text { Journal } \\
\end{array}$ & Japan & $\begin{array}{l}\text { 91, 1 C.M., survival; } \\
\text { "D" category; }\end{array}$ & $\begin{array}{l}249 \text { subsidiaries } \\
(123 \text { OECD, } 126 \\
\text { Africa) }\end{array}$ & Japan \\
\hline 11 & Zschoche (2016) & $\begin{array}{l}\text { Long Range } \\
\text { Planning }\end{array}$ & German parent MNEs & $\begin{array}{l}\text { 36, } 1 \text { C.M., divestment, } \\
\text { past performance, foreign } \\
\text { sales volume, } \\
\text { "A" category; }\end{array}$ & 631 firms & Germany \\
\hline 12 & $\begin{array}{l}\text { Meschi \& Métais } \\
(2015)\end{array}$ & $\begin{array}{l}\text { British Journal } \\
\text { of } \\
\text { Management }\end{array}$ & $\begin{array}{l}\text { French listed and non- } \\
\text { listed firms in USA }\end{array}$ & $\begin{array}{l}\text { 91, 1 C.M., acquirer ROA; } \\
\text { "B" category; }\end{array}$ & 741 acquisitions & USA \\
\hline 13 & $\begin{array}{l}\text { Sousa \& Tan } \\
(2015)\end{array}$ & $\begin{array}{l}\text { Journal of } \\
\text { International } \\
\text { Marketing }\end{array}$ & China & $\begin{array}{l}\text { 136, } 1 \text { C.M., exit; } \\
\text { "C" category; }\end{array}$ & 9930 firms & China \\
\hline 14 & $\begin{array}{l}\text { Damaraju, } \\
\text { Barney \& } \\
\text { Makhija (2015) }\end{array}$ & \begin{tabular}{|l|} 
Strategic \\
Management \\
Journal \\
\end{tabular} & USA parent firms & $\begin{array}{l}\text { 66, } 1 \text { C.M., divesting firm, } \\
\text { parent performance; } \\
\text { "B" category; }\end{array}$ & $\begin{array}{l}230 \text { sell-offs, } 153 \\
\text { spin-offs and } \\
\text { carve-outs }\end{array}$ & USA \\
\hline 15 & Li \& Liu (2015) & $\begin{array}{l}\text { Journal of } \\
\text { Business } \\
\text { Theory \& } \\
\text { Practice } \\
\end{array}$ & $\begin{array}{l}\text { Chinese Industrial } \\
\text { Enterprises }\end{array}$ & $\begin{array}{l}\text { 21, } 1 \text { C.M., divestment, } \\
\text { ROA; } \\
\text { "B" category; }\end{array}$ & $\begin{array}{l}28638 \text { divestments } \\
\text { in } 2006\end{array}$ & n.a. \\
\hline 16 & Song $(2015)^{*}$ & $\begin{array}{l}\text { Journal of } \\
\text { World } \\
\text { Business } \\
\end{array}$ & $\begin{array}{l}148 \text { Korean MNEs in } \\
43 \text { host countries }\end{array}$ & $\begin{array}{l}\text { 91, 1 C.M., subsidiary } \\
\text { performance; } \\
\text { "C" category; }\end{array}$ & $\begin{array}{l}2557 \text { foreign } \\
\text { manufacturing } \\
\text { subsidiaries }\end{array}$ & Korea \\
\hline 17 & $\begin{array}{l}\text { Wang \& Larimo } \\
(2015)\end{array}$ & $\begin{array}{l}13^{\text {th }} \text { Vaasa } \\
\text { Conference on } \\
\text { Int. Business }\end{array}$ & $\begin{array}{l}2123 \text { Finnish FDIs in } \\
59 \text { countries }\end{array}$ & $\begin{array}{l}\text { 91, 1 C.M. non-surviving } \\
\text { subsidiaries; } \\
\text { "D" category; }\end{array}$ & $\begin{array}{l}1345 \text { Finnish } \\
\text { acquisitions } \\
\text { (Sweden=267, } \\
\text { USA }=211 \text {, } \\
\text { Germany }=127 \text {, } \\
\text { UK=89 etc.) }\end{array}$ & Finland \\
\hline 18 & $\begin{array}{l}\text { Nyuur \& Debrah } \\
\text { (2014) }\end{array}$ & $\begin{array}{l}\text { Thunderbird } \\
\text { International }\end{array}$ & $\begin{array}{l}92 \text { foreign firms } \\
\text { operating in Ghana }\end{array}$ & $\begin{array}{l}\text { 28, 1 C.M. Termination; } \\
\text { "D" category; }\end{array}$ & 92 foreign firms & Ghana \\
\hline
\end{tabular}




\begin{tabular}{|c|c|c|c|c|c|c|}
\hline & & $\begin{array}{l}\text { Business } \\
\text { Review }\end{array}$ & & & & \\
\hline 19 & $\begin{array}{l}\text { Soule, } \\
\text { Swaminathan \& } \\
\text { Tihany } 2014 \\
\end{array}$ & $\begin{array}{l}\text { Strategic } \\
\text { Management } \\
\text { Journal } \\
\end{array}$ & $\begin{array}{l}449 \text { firms from } 32 \\
\text { countries had business } \\
\text { ties to Burma }\end{array}$ & $\begin{array}{l}\text { 231, 1 C.M. Divestment, } \\
\text { firm performance; } \\
\text { "D" category; }\end{array}$ & 2723 & Burma \\
\hline 20 & $\begin{array}{l}\text { Ewelt-Kanuer } \\
\text { Knauer \& } \\
\text { Thielemann } \\
(2014) \\
\end{array}$ & $\begin{array}{l}\text { Journal of } \\
\text { Business } \\
\text { Economics }\end{array}$ & European buyout exits & $\begin{array}{l}\text { 105, 1 C.M., exit degree; } \\
\text { "D" category; }\end{array}$ & $\begin{array}{l}1435 \text { European } \\
\text { buyout exits }\end{array}$ & Europe \\
\hline 21 & $\begin{array}{l}\text { Durand \& Vergne } \\
\text { (2014) }\end{array}$ & $\begin{array}{l}\text { Strategic } \\
\text { Management } \\
\text { Journal }\end{array}$ & $\begin{array}{l}\text { Firm divestments from } \\
\text { arms industry }\end{array}$ & $\begin{array}{l}\text { 136, } 1 \text { C.M., asset } \\
\text { divestment, performance; } \\
\text { "D" category; }\end{array}$ & $\begin{array}{l}202 \text { firms } 40 \% \\
\text { North American, } \\
29 \% \text { European, } \\
9 \% \text { Russian, } 6 \% \\
\text { Japanese and 4\% } \\
\text { Israeli firms }\end{array}$ & $\begin{array}{l}\text { Europe, } \\
\text { Israel, } \\
\text { Japan, North } \\
\text { America, } \\
\text { Russia }\end{array}$ \\
\hline 22 & $\begin{array}{l}\text { Elfenbein \& } \\
\text { Knott (2014) }\end{array}$ & $\begin{array}{l}\text { Strategic } \\
\text { Management } \\
\text { Journal } \\
\text { (forthcoming }\end{array}$ & $\begin{array}{l}\text { USA banking } \\
\text { industry, } 7798 \text { bank } \\
\text { divestments }\end{array}$ & $\begin{array}{l}\text { 210, } 1 \text { C.M., profit } \\
\text { indicator; } \\
\text { "A" category; }\end{array}$ & $\begin{array}{l}1340 \text { failures } 6458 \\
\text { unforced mergers }\end{array}$ & USA \\
\hline 23 & Farah (2014) & $\begin{array}{l}\text { Unpublished } \\
\text { PhD thesis }\end{array}$ & Japanese parent MNEs & $\begin{array}{l}\text { 136, } 1 \text { C.M., subsidiary } \\
\text { exit, parent ROA; } \\
\text { "A" category; }\end{array}$ & $\begin{array}{l}1540 \text { parent } \\
\text { MNEs, } 12101 \\
\text { foreign } \\
\text { subsidiaries, } 2757 \\
\text { foreign } \\
\text { subsidiaries } \\
\text { divestments }\end{array}$ & Japan \\
\hline 24 & $\begin{array}{l}\text { Pathak, } \\
\text { Hoskisson \& } \\
\text { Johnson (2014) }\end{array}$ & $\begin{array}{l}\text { Strategic } \\
\text { Management } \\
\text { Journal }\end{array}$ & USA public firms & $\begin{array}{l}\text { 171, 1 C.M., divestment } \\
\text { intensity, ROA; } \\
\text { "A" category; }\end{array}$ & $\begin{array}{l}227 \text { programs of } \\
\text { divestiture } \\
\text { comprising } 1395 \\
\text { individual } \\
\text { divestitures }\end{array}$ & USA \\
\hline 25 & $\begin{array}{l}\text { Pattnaik \& Lee } \\
\text { (2014) }\end{array}$ & $\begin{array}{l}\text { Asia Pacific } \\
\text { Business } \\
\text { Review }\end{array}$ & $\begin{array}{l}1697 \text { Korean } \\
\text { manufacturing MNEs }\end{array}$ & $\begin{array}{l}\text { 136, 1 C.M., foreign } \\
\text { affiliate divestment; } \\
\text { "D" category; }\end{array}$ & $\begin{array}{l}2435 \text { foreign } \\
\text { affiliates }\end{array}$ & Korea \\
\hline 26 & $\begin{array}{l}\text { Peng \& Beamish } \\
(2014)\end{array}$ & $\begin{array}{l}\text { Asia Pacific } \\
\text { Journal of } \\
\text { Management }\end{array}$ & $\begin{array}{l}\text { 1291 Japanese MNEs } \\
\text { in } 29 \text { host countries }\end{array}$ & $\begin{array}{l}\text { 190, 1 C.M., parent firm } \\
\text { ROA, subsidiary exit; } \\
\text { "A" category; }\end{array}$ & $\begin{array}{l}10236 \text { subsidiaries } \\
\text { across the globe }\end{array}$ & Japan \\
\hline 27 & Song $(2014 a)^{*}$ & $\begin{array}{l}\text { Management } \\
\text { International } \\
\text { Review }\end{array}$ & 101 Korean MNEs & $\begin{array}{l}\text { 120, 1 C.M., divestment } \\
\text { dummy, subsidiary } \\
\text { performance; } \\
\text { "D" category; }\end{array}$ & $\begin{array}{l}1557 \text { foreign } \\
\text { manufacturing } \\
\text { subsidiaries }\end{array}$ & Korea \\
\hline 28 & Song $(2014 b)^{*}$ & $\begin{array}{l}\text { Journal of } \\
\text { International } \\
\text { Management }\end{array}$ & $\begin{array}{l}\text { Korean manufacturing } \\
\text { MNEs }\end{array}$ & $\begin{array}{l}\text { 105, 1 C.M., exit, } \\
\text { subsidiary performance, } \\
\text { advertising intensity; } \\
\text { "A" category; }\end{array}$ & $\begin{array}{l}2534 \text { subsidiary } \\
\text { observations, of } \\
\text { which } 232 \\
\text { involved } \\
\text { divestments }\end{array}$ & Korea \\
\hline 29 & Song $(2014 c)^{*}$ & $\begin{array}{l}\text { Asia Pacific } \\
\text { Journal of } \\
\text { Management }\end{array}$ & 132 Korean MNEs & $\begin{array}{l}\text { 153, 1 C.M., exit, } \\
\text { subsidiary performance, } \\
\text { advertising intensity; } \\
\text { "A" category; }\end{array}$ & $\begin{array}{l}2234 \text { foreign } \\
\text { subsidiaries }\end{array}$ & Korea \\
\hline 30 & Praet (2013) & $\begin{array}{l}\text { Journal of } \\
\text { Family } \\
\text { Business } \\
\text { Strategy }\end{array}$ & $\begin{array}{l}48 \text { out of } 133 \text { listed } \\
\text { family firms in } \\
\text { Belgium }\end{array}$ & $\begin{array}{l}\text { 55, 1 C.M. Divestment, } \\
\text { diversification; } \\
\text { "D" category; }\end{array}$ & 48 family firms & Belgium \\
\hline
\end{tabular}




\begin{tabular}{|c|c|c|c|c|c|c|}
\hline 31 & Berry (2013) & $\begin{array}{l}\text { Organization } \\
\text { Science }\end{array}$ & $\begin{array}{l}759 \text { firms in } \\
\text { manufacturing } \\
\text { industries (US MNCs) }\end{array}$ & $\begin{array}{l}\text { 231, } 1 \text { C.M., performance, } \\
\text { parent ROA; "B" } \\
\text { category; }\end{array}$ & 12430 subsidiaries & USA \\
\hline 32 & $\begin{array}{l}\text { Chung, Lee, } \\
\text { Beamish, } \\
\text { Southam \& Nam } \\
\text { (2013) }\end{array}$ & $\begin{array}{l}\text { Journal of } \\
\text { World } \\
\text { Business }\end{array}$ & 812 Japanese MNEs & $\begin{array}{l}\text { 325, } 1 \text { C.M., subsidiary } \\
\text { divestment, MNE sales, } \\
\text { MNE advertising } \\
\text { intensity, international } \\
\text { diversification; } \\
\text { "A" category; }\end{array}$ & $\begin{array}{l}2850 \text { foreign } \\
\text { subsidiaries }\end{array}$ & Japan \\
\hline 33 & $\begin{array}{l}\text { Chung, Lee \& } \\
\text { Lee (2013a) }\end{array}$ & $\begin{array}{l}\text { Management } \\
\text { International } \\
\text { Review }\end{array}$ & $\begin{array}{l}479 \text { Korean MNEs in } \\
14 \text { Asia }\end{array}$ & $\begin{array}{l}\text { 459, } 3 \text { C.M., subsidiary } \\
\text { exit, advertising intensity, } \\
\text { subsidiary ROA; } \\
\text { "A" category; }\end{array}$ & $\begin{array}{l}703 \text { manufacturing } \\
\text { subsidiaries }\end{array}$ & Korea \\
\hline 34 & $\begin{array}{l}\text { Dai, Eden \& } \\
\text { Beamish (2013) }\end{array}$ & $\begin{array}{l}\text { Journal of } \\
\text { International } \\
\text { Business } \\
\text { Studies }\end{array}$ & $\begin{array}{l}433 \text { parent Japanese } \\
\text { firms in } 25 \text { countries } \\
\text { and } 54 \text { industries }\end{array}$ & $\begin{array}{l}\text { 276, 1 C.M., exit, } \\
\text { financial loss, parent sales; } \\
\text { "A + C" category; }\end{array}$ & $\begin{array}{l}670 \text { foreign } \\
\text { subsidiaries of } 433 \\
\text { Japanese parent } \\
\text { firms }\end{array}$ & Japan \\
\hline 35 & Xia \& Li (2013) & $\begin{array}{l}\text { Strategic } \\
\text { Management } \\
\text { Journal }\end{array}$ & $\begin{array}{l}\text { USA Benchmark } \\
\text { Input-Output by } \\
\text { Bureau of Economic } \\
\text { Analysis }\end{array}$ & $\begin{array}{l}\text { 136, 1 C.M., divestiture, } \\
\text { ROS, parent industry } \\
\text { performance; } \\
\text { "A" category; }\end{array}$ & $\begin{array}{l}2938 \text { sub-units } \\
\text { between the } \\
\text { acquisition and } \\
\text { divestiture dates }\end{array}$ & USA \\
\hline 36 & $\begin{array}{l}\text { Cui \& Kumar } \\
\text { (2012) }\end{array}$ & $\begin{array}{l}\text { Journal of } \\
\text { Business } \\
\text { Research }\end{array}$ & Termination of JVs & $\begin{array}{l}\text { 136, 1 C.M., parent firm } \\
\text { performance, parent firm } \\
\text { diversification; } \\
\text { "A" category; }\end{array}$ & $134 \mathrm{JVs}$ & USA \\
\hline 37 & $\begin{array}{l}\text { Fisch \& } \\
\text { Zschoche (2012) }\end{array}$ & $\begin{array}{l}\text { International } \\
\text { Business } \\
\text { Review }\end{array}$ & $\begin{array}{l}189 \text { German } \\
\text { manufacturing firms }\end{array}$ & $\begin{array}{l}\text { 153, } 1 \text { C.M., profitability; } \\
\text { "A" category; }\end{array}$ & $\begin{array}{l}143 \text { country exits } \\
\text { among } 596 \\
\text { country locations }\end{array}$ & Germany \\
\hline 38 & $\begin{array}{l}\text { Kim, Lu \& Rhee } \\
(2012)\end{array}$ & $\begin{array}{l}\text { Journal of } \\
\text { International } \\
\text { Business } \\
\text { Studies }\end{array}$ & $\begin{array}{l}\text { Subsidiaries of } \\
\text { Japanese firms }\end{array}$ & $\begin{array}{l}\text { 171, 1 C.M., subsidiary } \\
\text { exit, parent firm } \\
\text { performance, parent firm } \\
\text { advertising; } \\
\text { "D" category; }\end{array}$ & $\begin{array}{l}5047 \text { exits of } \\
15927 \text { Japanese } \\
\text { foreign } \\
\text { subsidiaries }\end{array}$ & Japan \\
\hline 39 & $\begin{array}{l}\text { Brauer \& } \\
\text { Wiersema (2012) }\end{array}$ & $\begin{array}{l}\text { Academy of } \\
\text { Management } \\
\text { Journal }\end{array}$ & $\begin{array}{l}\text { Divestitures of USA } \\
\text { firms }\end{array}$ & $\begin{array}{l}\text { 129, 1 C.M., sell-off, firm } \\
\text { performance, firm } \\
\text { diversification; } \\
\text { "A" category; }\end{array}$ & 2478 divestitures & USA \\
\hline 40 & $\begin{array}{l}\text { Decker \& } \\
\text { Mellewigt (2012) }\end{array}$ & $\begin{array}{l}\text { British Journal } \\
\text { of } \\
\text { Management }\end{array}$ & $\begin{array}{l}\text { Firms listed on } \\
\text { German Stock } \\
\text { Exchange }\end{array}$ & $\begin{array}{l}\text { 36, } 1 \text { C.M., exits, } \\
\text { diversification; } \\
\text { "D" category; }\end{array}$ & $\begin{array}{l}546 \text { observations } \\
\text { from } 91 \text { firms over } \\
\text { the period 1999- } \\
2004\end{array}$ & Germany \\
\hline 41 & $\begin{array}{l}\text { Polidoro, Ahuja, } \\
\text { \& Mitchell } \\
\text { (2011) }\end{array}$ & $\begin{array}{l}\text { Academy of } \\
\text { Management } \\
\text { Journal }\end{array}$ & $\begin{array}{l}97 \text { firms from Western } \\
\text { Europe, Japan and } \\
\text { USA }\end{array}$ & $\begin{array}{l}\text { 190, 1 C.M., JV } \\
\text { dissolution, performance } \\
\text { asymmetry; } \\
\text { "A + B" category; }\end{array}$ & $\begin{array}{l}\text { Dissolution of } 36 \\
\text { dyads and survival } \\
\text { of } 128 \text { dyads }\end{array}$ & $\begin{array}{l}\text { Western } \\
\text { Europe, } \\
\text { Japan and } \\
\text { USA }\end{array}$ \\
\hline 42 & $\begin{array}{l}\text { Park, Lee \& } \\
\text { Hong (2011) }\end{array}$ & $\begin{array}{l}\text { Management } \\
\text { Decision }\end{array}$ & $\begin{array}{l}61 \text { parent firms from } \\
27 \text { Korean business } \\
\text { groups }\end{array}$ & $\begin{array}{l}\text { 55, } 1 \text { C.M., pioneers; } \\
\text { "D" category; }\end{array}$ & $\begin{array}{l}500 \text { foreign } \\
\text { subsidiaries }\end{array}$ & Korea \\
\hline 43 & $\begin{array}{l}\text { Demirbag, } \\
\text { Apaydin, \& } \\
\text { Tatoglu (2011) }\end{array}$ & $\begin{array}{l}\text { Journal of } \\
\text { World } \\
\text { Business }\end{array}$ & $\begin{array}{l}\text { Thirty thousand } \\
\text { Japanese subsidiary } \\
\text { entries located in } \\
\text { MENA countries }\end{array}$ & $\begin{array}{l}\text { 136, } 1 \text { C.M., survival, } \\
\text { advertising intensity; } \\
\text { "D" category; }\end{array}$ & $\begin{array}{l}\text { 265 Japanese } \\
\text { subsidiaries in the } \\
\text { MENA countries } \\
\text { (including } \\
\text { divestments). }\end{array}$ & Japan \\
\hline
\end{tabular}




\begin{tabular}{|c|c|c|c|c|c|c|}
\hline 44 & $\begin{array}{l}\text { Wu, Xu \& Phan } \\
(2011)\end{array}$ & $\begin{array}{l}\text { Asia Pacific } \\
\text { Journal of } \\
\text { Management }\end{array}$ & 1210 Chinese firms & $\begin{array}{l}\text { 136, } 1 \text { C.M., corporate } \\
\text { divestitures, firm } \\
\text { diversification, firm } \\
\text { performance; } \\
\text { "A" category; }\end{array}$ & $\begin{array}{l}1439 \text { divestments } \\
\text { during 1999-2003 }\end{array}$ & China \\
\hline 45 & $\begin{array}{l}\text { Lee, Folta \& } \\
\text { Lieberman } \\
(2010)\end{array}$ & $\begin{array}{l}\text { Working } \\
\text { paper, } \\
\text { INSEAD }\end{array}$ & $\begin{array}{l}17 \text { technology } \\
\text { industries in the USA } \\
\text { between } 1989-2003\end{array}$ & $\begin{array}{l}\text { 381, } 2 \text { C.M., exits, related } \\
\text { diversification, ROS; } \\
\text { "D" category; }\end{array}$ & $\begin{array}{l}17875 \text { private } \\
\text { firms and } 2551 \\
\text { public firms }\end{array}$ & USA \\
\hline 46 & Berry (2010) & $\begin{array}{l}\text { Organization } \\
\text { Science }\end{array}$ & 190 USA firms & $\begin{array}{l}\text { 45, } 1 \text { C.M., divestment, } \\
\text { diversification, } \\
\text { performance; } \\
\text { "A" category; }\end{array}$ & 3453 divestments & USA \\
\hline 47 & $\begin{array}{l}\text { Brauer \& } \\
\text { Schimmer (2010) }\end{array}$ & $\begin{array}{l}\text { Journal of } \\
\text { Strategy and } \\
\text { Management }\end{array}$ & $\begin{array}{l}31 \text { firms from the Dow } \\
\text { Jones Global Stoxx } \\
\text { Insurance Index in } \\
\text { USA }\end{array}$ & $\begin{array}{l}\text { 36, } 1 \text { C.M., firm } \\
\text { performance, program } \\
\text { divestiture; } \\
\text { "A" category; }\end{array}$ & 157 divestitures & USA \\
\hline 48 & $\begin{array}{l}\text { Kim, Delios \& } \\
\text { Xu (2010) }\end{array}$ & $\begin{array}{l}\text { Journal of } \\
\text { Economic } \\
\text { Geography }\end{array}$ & $\begin{array}{l}\text { Foreign activities of } \\
\text { Japanese firms }\end{array}$ & $\begin{array}{l}\text { 253, } 1 \text { C.M., subsidiary } \\
\text { exit, parent firm ROA; } \\
\text { "B" category; }\end{array}$ & $\begin{array}{l}3416 \text { foreign } \\
\text { subsidiaries }\end{array}$ & Japan \\
\hline 49 & $\begin{array}{l}\text { Anand, Mesquita } \\
\text { \& Vassolo (2009) }\end{array}$ & $\begin{array}{l}\text { Academy of } \\
\text { Management } \\
\text { Journal }\end{array}$ & $\begin{array}{l}34 \text { biopharmaceutical } \\
\text { firms from England, } \\
\text { France, Germany, } \\
\text { Switzerland, Sweden, } \\
\text { US }\end{array}$ & $\begin{array}{l}\text { 132, } 2 \text { C.M., exit, prior } \\
\text { performance; } \\
\text { "A" category; }\end{array}$ & $\begin{array}{l}19 \text { firms from } \\
\text { USA, England, } \\
\text { France, Germany, } \\
\text { Switzerland and } \\
\text { Sweden. }\end{array}$ & $\begin{array}{l}\text { England, } \\
\text { France, } \\
\text { Germany, } \\
\text { Switzerland, } \\
\text { Sweden, } \\
\text { USA }\end{array}$ \\
\hline 50 & $\begin{array}{l}\text { Belderbos \& Zou } \\
(2009)^{*}\end{array}$ & $\begin{array}{l}\text { Journal of } \\
\text { International } \\
\text { Business } \\
\text { Studies }\end{array}$ & 412 Japanese firms & $\begin{array}{l}\text { 105, } 1 \text { C.M. divestment; } \\
\text { "D" category; }\end{array}$ & $\begin{array}{l}1095 \\
\text { manufacturing } \\
\text { affiliates in } \\
\text { electronics in nine } \\
\text { Asian countries or } \\
\text { regions }\end{array}$ & Japan \\
\hline 51 & $\begin{array}{l}\text { Coucke \& } \\
\text { Sleuwaegen } \\
(2008)\end{array}$ & $\begin{array}{l}\text { Journal of } \\
\text { International } \\
\text { Business } \\
\text { Studies } \\
\end{array}$ & $\begin{array}{l}\text { Manufacturing firms } \\
\text { from Belgium }\end{array}$ & $\begin{array}{l}28,1 \text { C.M., firm } \\
\text { productivity; } \\
\text { "D" category; }\end{array}$ & MNE subsidiaries & Belgium \\
\hline 52 & $\begin{array}{l}\text { Delios, Xu \& } \\
\text { Beamish (2008) }\end{array}$ & $\begin{array}{l}\text { Journal of } \\
\text { International } \\
\text { Business } \\
\text { Studies }\end{array}$ & Japanese firms & $\begin{array}{l}\text { 171, } 1 \text { C.M., subsidiary } \\
\text { exit, parent firm ROS, } \\
\text { corporate-level product } \\
\text { diversity; } \\
\text { "A" category; }\end{array}$ & 29279 subsidiaries & Japan \\
\hline 53 & $\begin{array}{l}\text { Moliterno } \\
\text { \&Wiersema } \\
(2007)\end{array}$ & $\begin{array}{l}\text { Strategic } \\
\text { Management } \\
\text { Journal }\end{array}$ & n.a. & $\begin{array}{l}\text { 66, 1 C.M., resource } \\
\text { divestment, divested } \\
\text { resource performance } \\
\text { (developed and less } \\
\text { developed); } \\
\text { "A" category; }\end{array}$ & 374 & n.a. \\
\hline 54 & $\begin{array}{l}\text { Belderbos \& Zou } \\
(2007)^{*}\end{array}$ & $\begin{array}{l}\text { Journal of } \\
\text { International } \\
\text { Business } \\
\text { Studies }\end{array}$ & 412 Japanese firms & $\begin{array}{l}\text { 153, 1 C.M., affiliate } \\
\text { growth; "D" category; }\end{array}$ & $\begin{array}{l}1041 \\
\text { manufacturing } \\
\text { affiliates in } \\
\text { electronics in nine } \\
\text { Asian countries or } \\
\text { regions }\end{array}$ & Japan \\
\hline
\end{tabular}




\begin{tabular}{|c|c|c|c|c|c|c|}
\hline 55 & $\begin{array}{l}\text { Gaur \& Lu } \\
(2007)\end{array}$ & $\begin{array}{l}\text { Journal of } \\
\text { Management }\end{array}$ & $\begin{array}{l}\text { 20177 Japanese } \\
\text { foreign subsidiaries }\end{array}$ & $\begin{array}{l}\text { 28, } 1 \text { C.M., survival or } \\
\text { exit; "D" category; }\end{array}$ & $\begin{array}{l}9633 \text { IJVs and } \\
10544 \text { WOS }\end{array}$ & Japan \\
\hline 56 & $\begin{array}{l}\text { Makino, Chan, } \\
\text { Isobe \& Beamish } \\
(2007)\end{array}$ & \begin{tabular}{|l|} 
Strategic \\
Management \\
Journal \\
\end{tabular} & $\begin{array}{l}\text { Japanese foreign } \\
\text { affiliate across the } \\
\text { world }\end{array}$ & $\begin{array}{l}45,1 \text { C.M., longevity } \\
\text { (survival duration); } \\
\text { "D" category; }\end{array}$ & $\begin{array}{l}999 \text { IJVs and } 2222 \\
\text { WOSs }\end{array}$ & Japan \\
\hline 57 & Xu \& Lu (2007) & \begin{tabular}{|l|} 
Journal of \\
Business \\
Research \\
\end{tabular} & $\begin{array}{l}\text { Japanese IJVs in } \\
\text { China }\end{array}$ & $\begin{array}{l}\text { 102, } 2 \text { C.M., IJV exit; } \\
\text { "D" category; }\end{array}$ & $\begin{array}{l}354 \text { Sino-Japanese } \\
\text { IJVs }\end{array}$ & Japan \\
\hline 58 & $\begin{array}{l}\text { Belderbos \& Zou } \\
(2006)^{*}\end{array}$ & $\begin{array}{l}\text { Working } \\
\text { paper, } \\
\text { Catholic } \\
\text { University of } \\
\text { Leuven }\end{array}$ & 412 Japanese firms & $\begin{array}{l}\text { 171, 1 C.M., divestment; } \\
\text { "D" category; }\end{array}$ & $\begin{array}{l}1078 \\
\text { manufacturing } \\
\text { affiliates in } \\
\text { electronics in nine } \\
\text { Asian countries or } \\
\text { regions }\end{array}$ & Japan \\
\hline 59 & $\begin{array}{l}\text { Chan, Makino \& } \\
\text { Isobe (2006) }\end{array}$ & $\begin{array}{l}\text { Journal of } \\
\text { International } \\
\text { Business } \\
\text { Studies } \\
\end{array}$ & $\begin{array}{l}\text { Subsidiaries of } \\
\text { Japanese MNEs }\end{array}$ & $\begin{array}{l}153,1 \text { C.M., exit counts in } \\
\text { host country, exit counts } \\
\text { of parent firm; } \\
\text { "D" category; }\end{array}$ & $\begin{array}{l}156451 \\
\text { observations }\end{array}$ & Japan \\
\hline 60 & $\begin{array}{l}\text { Hayward \& } \\
\text { Shimizu (2006) }\end{array}$ & $\begin{array}{l}\text { Strategic } \\
\text { Management } \\
\text { Journal }\end{array}$ & $\begin{array}{l}\text { USA based firms } \\
\text { acquired another USA } \\
\text { firm which divested }\end{array}$ & $\begin{array}{l}66,1 \text { C.M., divestiture, } \\
\text { acquired unit } \\
\text { performance, acquiring } \\
\text { firm performance; } \\
\text { "D" category; }\end{array}$ & $\begin{array}{l}68 \text { units divested } \\
\text { in } 68 \text { firms }\end{array}$ & USA \\
\hline 61 & Lu \& Xu (2006) & $\begin{array}{l}\text { Journal of } \\
\text { Management }\end{array}$ & $\begin{array}{l}\text { Japanese IJVs in } \\
\text { China }\end{array}$ & $\begin{array}{l}\text { 91, 1 C.M., IJV exit; } \\
\text { "D" category; }\end{array}$ & $\begin{array}{l}\text { 291 Sino-Japanese } \\
\text { IJVs }\end{array}$ & Japan \\
\hline 62 & $\begin{array}{l}\text { Sarkar, } \\
\text { Echambadi, } \\
\text { Agarwal \& Sen } \\
(2006)\end{array}$ & $\begin{array}{l}\text { Strategic } \\
\text { Management } \\
\text { Journal }\end{array}$ & $\begin{array}{l}33 \text { manufacturing US } \\
\text { industries }\end{array}$ & $\begin{array}{l}\text { 66, } 1 \text { C.M., firm exit, } \\
\text { diversified entrant; } \\
\text { "D" category; }\end{array}$ & 3433 firms & USA \\
\hline 63 & $\begin{array}{l}\text { Lu \& Hébert } \\
\text { (2005) }\end{array}$ & $\begin{array}{l}\text { Journal of } \\
\text { Business } \\
\text { Research }\end{array}$ & $\begin{array}{l}\text { Japanese foreign } \\
\text { subsidiaries in } 12 \\
\text { developing countries }\end{array}$ & $\begin{array}{l}\text { 66, } 1 \text { C.M., survival, } \\
\text { advertising intensity, } \\
\text { parent profitability; } \\
\text { "A" category; }\end{array}$ & $\begin{array}{l}720 \text { IJVs and } 119 \\
\text { divestments }\end{array}$ & Japan \\
\hline 64 & $\begin{array}{l}\text { Shimizu \& Hitt } \\
\text { (2005) }\end{array}$ & $\begin{array}{l}\text { Journal of } \\
\text { Management }\end{array}$ & $\begin{array}{l}\text { USA based firms } \\
\text { acquired another USA } \\
\text { firm which divested }\end{array}$ & $\begin{array}{l}\text { 78, } 1 \text { C.M., divestiture, } \\
\text { acquirer firm } \\
\text { performance, } \\
\text { acquired unit } \\
\text { performance; } \\
\text { "A + C" category; }\end{array}$ & 70 cases & USA \\
\hline 65 & Berry (2004) & $\begin{array}{l}\text { Working } \\
\text { paper, } \\
\text { Wharton } \\
\text { School } \\
\end{array}$ & $\begin{array}{l}190 \text { USA } \\
\text { manufacturing firms }\end{array}$ & $\begin{array}{l}\text { 28, } 1 \text { C.M., divest, ROS, } \\
\text { diversification; } \\
\text { "A" category; }\end{array}$ & $\begin{array}{l}3642 \text { observations } \\
\text { of divestments }\end{array}$ & USA \\
\hline 66 & $\begin{array}{l}\text { Delios \& } \\
\text { Beamish (2001) }\end{array}$ & $\begin{array}{l}\text { Academy of } \\
\text { Management } \\
\text { Journal } \\
\end{array}$ & 4000 Japanese firms & $\begin{array}{l}\text { 78, } 1 \text { C.M., survival, } \\
\text { profitability, advertising; } \\
\text { "A" category; }\end{array}$ & 12204 subsidiaries & Japan \\
\hline 67 & $\begin{array}{l}\text { Van Kranenburg, } \\
\text { Cloodt \& } \\
\text { Hagedoorn } \\
(2001)\end{array}$ & $\begin{array}{l}\text { International } \\
\text { Studies of } \\
\text { Management } \\
\& \\
\text { Organization }\end{array}$ & $\begin{array}{l}3 \text { Dutch multinational } \\
\text { publishing companies }\end{array}$ & $\begin{array}{l}\text { 91, 1 C.M., divestment, } \\
\text { traditional diversification; } \\
\text { "D" category; }\end{array}$ & $\begin{array}{l}175 \text { investment } \\
\text { events }\end{array}$ & Dutch \\
\hline
\end{tabular}




\begin{tabular}{|c|c|c|c|c|c|c|}
\hline 68 & $\begin{array}{l}\text { Mata \& Portugal } \\
(2000)\end{array}$ & $\begin{array}{l}\text { Strategic } \\
\text { Management } \\
\text { Journal }\end{array}$ & 1033 foreign firms & $\begin{array}{l}\text { 78, 1 C.M., } \\
\text { diversification; } \\
\text { "D" category; }\end{array}$ & 1033 & n.a. \\
\hline 69 & $\begin{array}{l}\text { Haynes, } \\
\text { Thompson \& } \\
\text { Wright (2000) }\end{array}$ & $\begin{array}{l}\text { International } \\
\text { Journal of } \\
\text { Industrial } \\
\text { Organization }\end{array}$ & $\begin{array}{l}134 \text { UK firms from } \\
1985 \text { FT500 }\end{array}$ & $\begin{array}{l}\text { 190, 1 C.M., no of } \\
\text { divestments, ROS; } \\
\text { "A" category; }\end{array}$ & 1149 divestments & UK \\
\hline 70 & $\begin{array}{l}\text { Steensma \& } \\
\text { Lyles (2000) }\end{array}$ & $\begin{array}{l}\text { Strategic } \\
\text { Management } \\
\text { Journal }\end{array}$ & $\begin{array}{l}\text { Manufacturing IJVs } \\
\text { located in Hungary }\end{array}$ & $\begin{array}{l}\text { 120, } 1 \text { C.M., survival; } \\
\text { "D" category; }\end{array}$ & $\begin{array}{l}132 \text { manufacturing } \\
\text { IJVs }\end{array}$ & $\begin{array}{l}\text { Western } \\
\text { Countries }\end{array}$ \\
\hline 71 & $\begin{array}{l}\text { Chang \& Singh } \\
\text { (1999) }\end{array}$ & $\begin{array}{l}\text { Strategic } \\
\text { Management } \\
\text { Journal }\end{array}$ & $\begin{array}{l}772 \text { public } \\
\text { corporations in USA } \\
\text { (main business } \\
\text { manufacturing) }\end{array}$ & $\begin{array}{l}\text { 78, } 1 \text { C.M., ROA, } \\
\text { diversification; } \\
\text { "B" category; }\end{array}$ & $\begin{array}{l}1202 \text { exits out of } \\
2787 \text { cases of } \\
\text { entry }\end{array}$ & USA \\
\hline 72 & $\begin{array}{l}\text { Mariotti \& } \\
\text { Piscitello (1999) }\end{array}$ & $\begin{array}{l}\text { Transnational } \\
\text { Corporations }\end{array}$ & 340 Italian TNCs & $\begin{array}{l}\text { 120, 1 C.M., } \\
\text { diversification; } \\
\text { "D" category; }\end{array}$ & $\begin{array}{l}1067 \text { foreign } \\
\text { affiliates }\end{array}$ & Italy \\
\hline 73 & Benito (1997b) & $\begin{array}{l}\text { Applied } \\
\text { Economics }\end{array}$ & $\begin{array}{l}182 \text { subsidiaries of } 93 \\
\text { Norwegian } \\
\text { manufacturing firms }\end{array}$ & $\begin{array}{l}\text { 66, } 1 \text { C.M., diversified } \\
\text { parent; } \\
\text { "D" category; }\end{array}$ & $\begin{array}{l}108 \text { exits during } \\
\text { period } 1982 \text { to } \\
1992\end{array}$ & Norway \\
\hline 74 & Bergh (1997) & $\begin{array}{l}\text { Strategic } \\
\text { Management } \\
\text { Journal }\end{array}$ & $\begin{array}{l}\text { USA manufacturing } \\
\text { firms that had } \\
\text { acquired unrelated } \\
\text { manufacturing firms }\end{array}$ & $\begin{array}{l}\text { 91, } 2 \text { C.M., ROA, } \\
\text { diversification; } \\
\text { "B" category; }\end{array}$ & $\begin{array}{l}135 \text { unrelated } \\
\text { acquisitions in } \\
1977 \text { and } 140 \text { in } \\
1987\end{array}$ & USA \\
\hline 75 & $\begin{array}{l}\text { Park \& Ungson } \\
\text { (1997) }\end{array}$ & $\begin{array}{l}\text { Academy of } \\
\text { Management } \\
\text { Journal }\end{array}$ & $\begin{array}{l}430 \text { joint ventures } \\
\text { Japan, USA }\end{array}$ & $\begin{array}{l}\text { 78, 1 C.M., dissolution; } \\
\text { "D" category; }\end{array}$ & $\begin{array}{l}137 \text { cross-border } \\
\text { and } 49 \text { domestic } \\
\text { joint ventures }\end{array}$ & Japan, USA \\
\hline 76 & $\begin{array}{l}\text { Shaver, Mitchell } \\
\text { \& Yeung (1997) }\end{array}$ & $\begin{array}{l}\text { Strategic } \\
\text { Management } \\
\text { Journal } \\
\end{array}$ & 311 USA firms & $\begin{array}{l}\text { 28, } 1 \text { C.M., survival, } \\
\text { parent financial data; } \\
\text { "D" category; }\end{array}$ & $\begin{array}{l}237 \text { acquisitions } \\
\text { and } 117 \text { new } \\
\text { plants }\end{array}$ & USA \\
\hline 77 & Li (1995) & $\begin{array}{l}\text { Strategic } \\
\text { Management } \\
\text { Journal }\end{array}$ & $\begin{array}{l}\text { Foreign firms entering } \\
\text { the USA market }\end{array}$ & $\begin{array}{l}\text { 301, 3 C.M., exit, } \\
\text { diversification; } \\
\text { "D" category; }\end{array}$ & $\begin{array}{l}267 \text { new foreign } \\
\text { subsidiaries and } \\
1235 \text { at risk } \\
\text { foreign } \\
\text { subsidiaries } \\
\end{array}$ & USA \\
\hline 78 & Markides (1995) & $\begin{array}{l}\text { Strategic } \\
\text { Management } \\
\text { Journal } \\
\end{array}$ & $\begin{array}{l}1985 \text { Fortune } 500 \text { list } \\
\text { in USA }\end{array}$ & $\begin{array}{l}\text { 78, } 1 \text { C.M., profitability, } \\
\text { advertising; } \\
\text { "D" category; }\end{array}$ & 200 firms & USA \\
\hline 79 & $\begin{array}{l}\text { Hoskisson, } \\
\text { Johnson \& } \\
\text { Moesel (1994) }\end{array}$ & $\begin{array}{l}\text { Academy of } \\
\text { Management } \\
\text { Journal }\end{array}$ & $\begin{array}{l}\text { Firm initiated } \\
\text { programmes of } \\
\text { divestitures in USA }\end{array}$ & $\begin{array}{l}\text { 253, 1 C.M., number of } \\
\text { divestitures, relative ROA, } \\
\text { relative product } \\
\text { diversification; } \\
\text { "B" category; }\end{array}$ & 203 firms & USA \\
\hline \multirow[t]{3}{*}{80} & $\begin{array}{l}\text { Baden-Fuller } \\
\text { (1989) }\end{array}$ & $\begin{array}{l}\text { The Economic } \\
\text { Journal }\end{array}$ & $\begin{array}{l}28 \text { steel foundries } \\
\text { closed during 1975- } \\
1983 \text { in UK }\end{array}$ & $\begin{array}{l}\text { 36, } 1 \text { C.M., closure, } \\
\text { profits, diversification; } \\
\text { "A" category; }\end{array}$ & $\begin{array}{l}8 \text { closures, } 3 \\
\text { management } \\
\text { buyouts, } 25 \text { non- } \\
\text { closures }\end{array}$ & UK \\
\hline & & & & $\begin{array}{l}\text { Total correlations }=10877 \\
\text { Total C.M. }=87 \\
\text { Total "A" category=29 } \\
\text { Total "B" category=8 } \\
\text { Total "C" category=4 } \\
\text { Total "D" category=35 } \\
\text { A+B=1, A+C=2, B+C=1. }\end{array}$ & & \\
\hline & & & & & & \\
\hline
\end{tabular}


Notes:

*All studies are based on databases, except for the last paper, which uses interviews. The full list of articles used in the meta-analysis can be obtained from the author upon request. The three papers by Belderbos and Zou (2006, 2007, 2009) although having different matrices are based on the same investigation in Japan. In the analysis I consider all their papers as they are based on different models. Regarding the papers by Song, I include all five of them as all investigations are based on different models. Four studies were excluded from the current analysis, as follows: The study by Li (2008) did not measure divestment or subsidiary exit in their correlation matrices. The study by Park and Russo (1996) was problematic as in their correlation matrices no relevant constructs were studied similar to the ones in this study except for IJV failure, total resource divestment, and IJV dissolution, respectively. In addition, the study by Reuer and Tong (2005) examined call option and was excluded from the analysis. Finally, the study by Fischer and Pollock (2004) was not included in the analysis as these authors investigated IPO firm failure.

** The 80 studies are divided into four categories ("A"; "B"; "C"; and "D"): "A" category includes those studies which indicate a relationship between divestment/subsidiary exit to performance/profitability; " $\mathrm{B}$ " category includes those studies which indicate a relationship between divestment/subsidiary exit to parent ROA; "C" category includes those studies which indicate a relationship between divestment/subsidiary exit to subsidiary performance/profitability/ROA; and " $\mathrm{D}$ " category includes those studies that do not include any relationship between divestment/subsidiary exit to either parent or subsidiary performance/profitability/ROA.

*** n.a. $=$ non-available

**** Song (2015) uses two models for statistical analysis. First, he uses feasible generalised least squares (FGLS) to analyse subsidiary performance. Second, he uses Cox's proportional hazard model (CPHM) to analyse subsidiary survival. In our study, we include only those models which were used to test survival/divestment propositions.

*****KBV: Knowledge based view; NBV: Network based view; RBV: Resource-based view; ROT: Real options theory; TCE: Transaction cost economics; CPHM: Cox's proportional hazard model; SEM: Structural equation modeling. 